ANL/MHD-78-4

ANL/MHD-78-4

la

330178

$12-1^{2}-1809$

$90^{9}$ Thestall

\title{
EVALUATION OF AVAILABLE \\ MHD SEED-REGENERATION PROCESSES \\ ON THE BASIS OF ENERGY CONSIDERATIONS
}

by

A. C. Sheth and T. R. Johnson

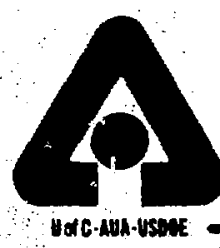

ARGONNE NATIONAL LABORATORY, ARGONNE, ILLINOIS

Proparod for the U. S. DEPARTMENT OF ENERGYIFossil Energy MHD Division 
Distribution Categories:

Cual Conversion and

Litilization-MHD (LC-90g)

Energy Conversion (LC-93)

ANI / MHD- 78-4

A..............

ARCONNE NAT TONA, IAABORATURY

9700 South Cass Avenue

Argonne, J11inois 60439

EVALATION OF AVAIIARLE MHD SEFD-RECENERATION PROCESGES

ON THE PASIS OF BNERGY CONSIDERATIINS

by

A. C. Sheth and T. R. Johnson

Chemica? Engineering Division

September 1978 
TABLE OF CONTENTS

Page

ABSTRACT ............................... 1

I. INTRODUCTION . . . . . . . . . . . . . . . . . . 2

II. AVAILABLE SEED REGENERATION PROCESSES . . . . . . . . . . 5

A. PERC Process . . . . . . . . . . . . . . . 5

B. Aqueous Carbonate Process ... . . . . . . . . . . . 5

C. Modified Tampella Process .. . ... . . . . . . . . 6

D. Markant Process ..................... 7

E. Enge1-Precht Process . . . . . . . . . . . . . . 8

F. Formate Processes ................... 8

G. Double Alkali/Causticization/Hydrated Lime Processes . . . . 9

III. PROCESS CONSIDERATIONS . . . . . . . . . . . . . . 9

IV. SHLFUR-RECOVERY PROCESSES . . . . . . . . . . . . . . 11

A. Claus Process ................... 12

B. Stretford Process . . . . . . . . . . . . . . 13

v. SEED RECOVERY . . . . . . . . . . . . . . . . . . 13

VI. ANALYSIS OF PERC PROCESS . . . . . . . . . . . . . . . 17

VII. ANALYSIS OF MODIFIED TAMPELLA PROCESS . . . . . . . . . . . 22

vIII. COMPARISON OF ENERGY REQUIREMENTS FOR PERC
AND TAMPELLA PROCESSES . . . . . . . . . . . . . . . . 27

IX. ECONOMIC COMPARISON . . . . . . . . . . . . . . . 29

x. Conclustons . . . . . . . . . . . . . . . . . . 31

XI. RECOMMENDATIONS . . . . . . . . . . . . . . . . 31

A. Modified Tampella Process . . . . . . . . . . 32

B. PERC Process . . . . . . . . . . . . . . . 32

C. General ................... 33

ACKNOWLEDGMENTS . . . . . . . . . . . . . . . . . . 33

REFERENCES . . . . . . . . . . . . . . . . . . . 34

APPENDIX . . . . . . . . . . . . . . . . . . . . . 36 


\section{LIST OF FIGURES}

No.

Title

Page

1. Schematic of Seed-Recovery Process . . . . . . . . . . . . 14

2. Seed-Regeneration Scheme Based on the PERC Process . . . . . . . 17

3. Seed-Regeneration Scheme Based on Modified

Tampella Process . . . . . . . . . . . . . . . . .

\section{LIST OF TABLES}

No.

Title

Page

1. Conditions and Assumptions Used in Evaluation . . . . . . . . 3

2. Characteristics of Washed Illinois 非 Coal . . . . . . . . . 3

3. Flow Chart for Seed-Recovery System . . . . . . . . . . . 16

4. Flow Chart for Scheme Based on PERC Process . . . . . . . . . 20

5. Overall Energy Balance for Scheme Based on PERC Process . . . . 21

6. Flow Chart for Scheme Based on Modified Tampella Process . . . . 25

7. Overall Energy Balance for Scheme Based on Modified Tampella Process . . . . . . . . . . . . . 26

8. Comparison of Energy Requirements per Hour for Various Seed-Reprocessing Schemes . . . . . . . . . . . . . 28

9. Comparison of Industrial Energy Requirements for Tampella Process with Requirements Calculated in This Study

10. Economic Comparison of Various Seed-Reprocessing Schemes . . . . 30 
EVALUATION OF AVAILABLE MHD SEED-REgENERATION PROCESSES

ON THE BASIS OF ENERGY CONSIDERATIONS

by

A. C. Sheth and T. R. Johnson

\begin{abstract}
of the several processes described in the literature that are capable of separating sulfur from alkali-metal sulfates, seven processes werc selected as candidates for regenerating seed material for reuse in open-cycle MHD. After a brief assessment of each process, two were selected for a detalled analysis, namely, a process developed by the Pittsburgh Energy Research Center (PERC) and a modifled version of the Tampella process. The processes were compared on the bases of energy requirements and the amount of research work needed to develop a seed-regeneration process for MHD systems. The energy requirements given should be considered as rough values, because factors such as heat losses and component efficiency were not included in the analysis. On the basis of energy consumption, the PERC process has a slight advantage over the Tampella process; on the basis of the present state of development of various coxponents, the Tampella process has a clear advantage. Accordingly, it was recommended that developmental programs be carried out for both the PERC and Tampella processes.
\end{abstract}




\section{INTRODUCTION}

The ofen-cycle, coal-fired MHD power system, in addition to having a higher efficiency than other fossil-fueled power systems, has the advantage of a self-contained sulfur-removal capacity. The potasslum seed plays a dual role, first, by increasing the electrical conductivity of the hot combustion gases by thermal ionization and, second, by eliminating $\mathrm{SO}_{2} \mathrm{f}$-om the gaseous effluent. The spent seed is collected in varlous downstream components, predominantly as a mixture of water-soluble salts, $\mathrm{K}_{2} \mathrm{CO}_{3}$ and $\mathrm{K}_{2} \mathrm{SO}_{4}$, contaminated with fly ash. Because of the high cost of seed (about $\$ 0.20 / 1 \mathrm{~b}$ for $\mathrm{K}_{2} \mathrm{CO}_{3}$ and about $\$ 0.05 / 1 \mathrm{~b}$ of $\left.\mathrm{K}_{2} \mathrm{SO}_{4}\right)$, and the large quantities of seed required, a potassium throw-away system for sulfur removal is posstble only if there is an adequate supply of $\mathrm{K}_{2} \mathrm{CO}_{3}$ and sufficient demand for $\mathrm{K}_{2} \mathrm{SO}_{4}$. At present, it is not economically feasible to consider a potassium throw-away system; therefore, to exploit the desulfurization capability of the MHD seed material, sufficient quantities of sulfur must be separated from the recovered $\mathrm{K}_{2} \mathrm{SO}_{4}$, to allow the seed to be reused.

Several processes described in the literature are capable of saparating sulfur from alkali metal sulfates but at present none are directly applicable to MHD seed recovery. Some processes have nover been fully developed and most of the conmercial processes either were developed especially for solium salts or are not easily adaptable to an MHD system. Data for engineering design and deve opment of a complete seed-regeneration system for MHD are either not available, or are incomplete.

This report describes a study performed at Argonne National Laboratory (ANL) to evaluate available processes and recommend the most promising for further development. Concurrent1y, a similar but independent evaluation was conducted at the University of Tennessee Space Institute.

To maintain uniformity, a common set of conditions and assumptions was adopted for both evaluations. These are summarized in Table 1.1

Table 2 1ists the characteristics of Illinois $\$ 6$ coal, which provided a uniform coal composition for both evaluations.

Other constraints imposed on the evaluations were as follows: (1) fluegas scrubbing processes and processes yielding sulfur in the form of a waste solid compound (e.g., $\mathrm{CaSO}_{4} \cdot 2 \mathrm{H}_{2} \mathrm{O}$ ) were to bs excluded from consideration and (2) the sulfur recovery step was to be carried out only to the stage of elemental sulfur.

Calculations showed that, for the conditions adopted for the evaluation, about $85 \%$ of the $\mathrm{K}_{2} \mathrm{SO}_{4}$ would have to be converted to $\mathrm{K}_{2} \mathrm{CO}_{3}$ to restore the desulfurization capability of the MHD seed. 
Table 1. Conditions and Assumptions Used in Evaluation.

Size of plant: $1000 \mathrm{MWt}$

Net electrical efficiency: $50 \%$

Type of coal: washed Illinois \#6

Sulfur content of coal: 3 to 3.5 wt \%

Seeding level: 1 wt \% in flue gases

$\mathrm{K} / \mathrm{S}$ ratio: at 1 east $10 \%$ excess over that required to react with sufficient sulfur in the coal to meet EPA emission limits (1.2 $1 \mathrm{~b} \mathrm{SO}_{2} / 10^{6} \mathrm{Btu}$ ).

Overall efficiency for potassium recovery: 95\%

Composition of spent seed mixture: 95 wt $\% \mathrm{~K}_{2} \mathrm{SO}_{4}+\mathrm{K}_{2} \mathrm{CO}_{3}$, 5 wt \% fly ash

Ash Analysis

Tab1e 2. Characteristics of Washed I11inois $\# 6$ Coal (Source: Burning Stone " Strip Mine) ${ }^{a}$

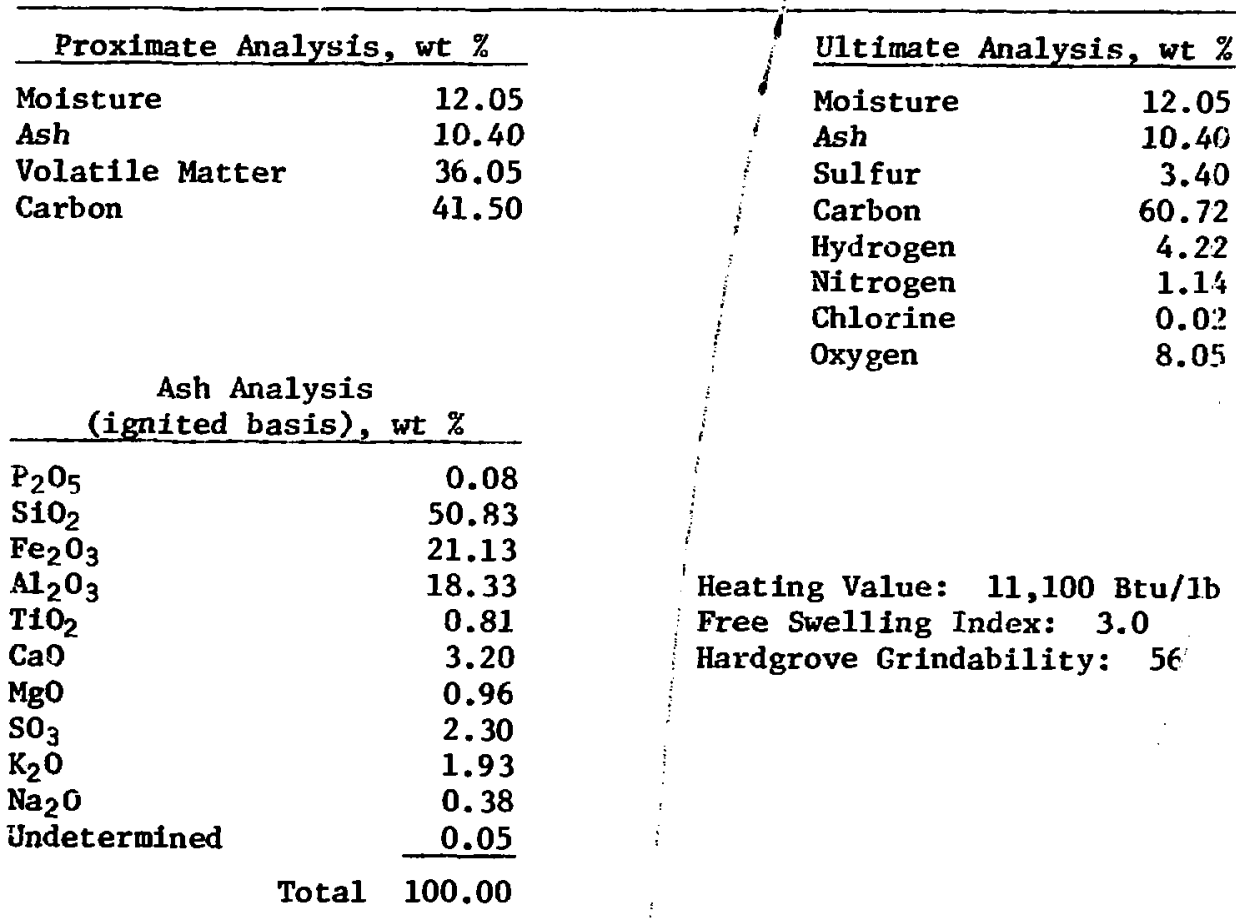

${ }^{\mathrm{a}}$ See Ref. 2 . 
In the evaluation study reported here, seven processes for separating sulfur from alkali metals were selected for assessment: (1) the PERC process (developed by the Pittsburgh Energy Research Center), ${ }^{3}$ (2) the Aqueous Carbonate (AC) process, 4 (3) the Tampella process, 5 (4) the Markant process, 6 (5) the Engel-Precht process, 7 (6) the Formate process, $8-10$ and (7) the DrubleAlkail process. ${ }^{9}$ On the basis of the above-mentioned ground rules, some of the processes were ruled out. Detailed mass and heat balance calculations were carried out for the PERC and modified Tampella processes. The calculated results were then utilized to compare these two processes with respect to their energy requirements. Two processes were considered for sulfur recovery: the Claus process ${ }^{1}$ and the Stretford process. 11 ia the latter process was selected for sulfur recovery following the seed regeneration. Owing to inadequate information on the Stretford process, the sulfur recovery step was included in the mass balance calculations but not in the heat balance calculations.

Because kinetic and thermodynamic data for the selected processes are unreliable and/or incomplete, economic evaluations and comparisons are difficult and inconclusive. For example, the University of Tennessee Space Institute (UTSI) $1 \mathrm{lb}$ estimated that the cost of regeneration by the PERC process will be about $5.68 \mathrm{mills} / \mathrm{kWh}$ for a 1000 MWe MHD power plant using coal containing 4.1 wt \% sulfur. In a similar study of the PERC process, Westinghouse ${ }^{12}$ estimated a cost of about $1.70 \mathrm{mills} / \mathrm{kWh}$ for a 220 MWe MHD power plant using $0.8 \mathrm{wt} \%$ sulfur coal, with a cost breakdown of $25 \%$ for fixed cost of gasifier and reactors, $32 \%$ for fixed cost of equipment other than the gasifier and reactors, and $43 \%$ for operating costs and cost of coal. When we adjusted the Westinghouse estimates for a 1000 MWe plant and $4.1 \mathrm{wt} \%$ sulfur coal, the seed regeneration cost was $5.17 \mathrm{mills} / \mathrm{kWh}$; the cost breakdown in this case, was $12 \%$ for fixed cost of gasifier and reactors, $15 \%$ for fixed cost of equipment other than gasifier and reactors, and $73 \%$ for operating costs, mainly for coal. Although the $5.17 \mathrm{mills} / \mathrm{kWh}$ figure agrees well with the UTSI estimate of $5.68 \mathrm{mills} / \mathrm{kWh}$, it can be seen from the cost breakdowns that seed regeneration cost for small plants is sensitive to the cost of the reactors and gasifier, and for larger plants it is sensitive to the gas utilization. The Westinghouse cost and our adjusted value of $5.17 \mathrm{mills} / \mathrm{kWh}$ were based on $21 \%$ gas utilization; however, PERC $^{12}$ has used gas utilizations as high as $85 \%$ in their studies. When the cost value based on the Westinghouse estimate was further adjusted for $85 \%$ gas utilization, thus reducing the capital cost of the gasifier and the cost of coal, the seed regeneration cost was only $2.09 \mathrm{mills} / \mathrm{kWh}$. Thus, knowledge of reaction rates, gas utilization, and chemical equilibria is very important in making reasonable cost estimates. Infornation on materials of construction, component design, and fabrication are also important. However, these kinds of information were not available for the seed regeneration processes selected for this study; therefore, economic comparisons seemed unjustified. Instead, our evaluations were based primarily on the technical feasibility of a process, its stage of development, and compatibility of the process with the environment.

The MHD development program sponsored by DOE has the goal of commercial MHD demonstration by the late $1980^{\prime} \mathrm{s}$. The first majnr milestone in meeting this goal is a pilot-scale Engineering Test Facility (ETF). As a part of the complete plant, ETF should contain seed-recovery and -regeneration systems. Westinghouse Electric Corp. and AVCo Everett Research Laboratory, Inc. have proposed conceptual seed recycle systems for ETF. In their work, both the 
contractors have critically reviewed some of the available seed regeneration processes. Information given in these two contractors' preliminary reports ${ }^{9,12}$ has been considered for the evaluations in this report.

In this report, most of the units used in calculations are those commonly used in industrial and engineering technologies. For the convenience of readers who may wish to perform calculations in metric (SI) units, appropriate conversion factors are given in the Appendix.

\section{AVAILABLE SEED-REGENERATION PROCESSES}

From among the various applicable processes described in the literature, the following seven processes were selected as possible candidate processes for seed regeneration.

\section{A. PERC Process}

The chemical reactions involved in the PERC $^{3}$ process are as follows:

$$
\begin{aligned}
& \mathrm{K}_{2} \mathrm{SO}_{4}+\mathrm{xCO}+(4-\mathrm{x}) \mathrm{H}_{2} \stackrel{700-800^{\circ} \mathrm{C}}{\longrightarrow} \mathrm{K}_{2} \mathrm{~S}+\mathrm{xCO}_{2}+(4-x) \mathrm{H}_{2} \mathrm{O} \\
& \mathrm{K}_{2} \mathrm{~S}+\mathrm{CO}_{2}+\mathrm{H}_{2} \mathrm{O} \stackrel{500^{\circ} \mathrm{C}}{\longrightarrow} \mathrm{K}_{2} \mathrm{CO}_{3}+\mathrm{H}_{2} \mathrm{~S}
\end{aligned}
$$

From the 1 inited data obtained at the Pittsburgh Energy Research Center (PERC), values for the percentage gas utilization were calculated and reported by AVCO Everett Research Jaboratory. ${ }^{9}$ AVCO calculated that for reductants of pure hydrogen and pure carbon monoxide, both at $750^{\circ} \mathrm{C}$, the gas utilization values per pass were on $1 y 2.5$ and $2 \%$, respectively. For the regeneration step at $500{ }^{\circ} \mathrm{C}$, AVCO calculated that for a mixture of $50 \% \mathrm{CO}_{2}$ and $50 \%$ steam only $3.9 \%$ of the $\mathrm{CO}_{2}$ was utilized per pass. However, with mixtures of $\mathrm{CO}$ and $\mathrm{H}_{2}, \mathrm{coal}$, producer gas, etc. and different reactor designs with gas recycle and stagewise operations, it may be possibie to improve the gas utilization in this process. Theoretical equilfbrium calculations indicate the possibility of obtaining higher gas utilizations (up to about 90\%). A coal gasifier is required in this process; however, extensive cleaning of the gasifier effluent to remove $\mathrm{CO}_{2}$, tarry materials, and particulates is not required. The main disadvantage of this process is that it requires three high-temperature operations, namely, coal gasification, seed reduction, and seed carbonation/oxidation. Another possible problem is caused by phase changes during the reduction step, which could cause the reaction mixture to melt and then resolidify.

\section{B. Aqueous Carbonate Process}

The Aqueous Carbonate (AC) process was developed and has been tested in a pilot plant for a sodium system by Atomics International. 4 A modified version for the potassium system would have similar chemical steps, as indicated below. 


\section{In reducer}

$$
\mathrm{K}_{2} \mathrm{SO}_{4}(\ell)+2 \mathrm{C}\left(\mathrm{coal} \text { or coke) } \stackrel{900^{\circ} \mathrm{C}}{\longrightarrow} \mathrm{K}_{2} \mathrm{~S}(\ell)+\mathrm{CO}_{2}\right.
$$

In precarbonator

$$
2 \mathrm{~K}_{2} \mathrm{~S}+\mathrm{H}_{2} \mathrm{O}+\mathrm{CO}_{2} \stackrel{\mathrm{aq}}{\longrightarrow} 2 \mathrm{KHS}+\mathrm{K}_{2} \mathrm{CO}_{3}
$$

The entire aqueous solution containing potassium salts is transferred to the carbonator, where the following reactions occur:

$$
\begin{aligned}
& \mathrm{KHS}+\mathrm{CO}_{2}+\mathrm{H}_{2} \mathrm{O} \stackrel{\mathrm{aq}}{\longrightarrow} \mathrm{KHCO}_{3}+\mathrm{H}_{2} \mathrm{~S} \\
& 2 \mathrm{KHS}+\mathrm{CO}_{2}+\mathrm{H}_{2} \mathrm{O} \stackrel{\mathrm{aq}}{\longrightarrow} \mathrm{K}_{2} \mathrm{CO}_{3}+2 \mathrm{H}_{2} \mathrm{~S}
\end{aligned}
$$

Liquid effluent from the carbonator, upon evaporation/crystallization, yields $\mathrm{K}_{2} \mathrm{CO}_{3}$.

A recent Westinghouse report ${ }^{12}$ points out that the estimated capital cost for a plant handling $10 \mathrm{~kg} / \mathrm{s}$ of $\mathrm{K}_{2} \mathrm{SO}_{4}$, and using the $\mathrm{AC}$ process to completely convert sulfate to carbonate will be $\$ 44.1 \times 10^{6}$. For a plant handiing 1.25 $\mathrm{kg} / \mathrm{s}$ of $\mathrm{K}_{2} \mathrm{SO}_{4}$ (about $192 \mathrm{MWt}$ size) and using Illinois coal in the MHD combustor, the net energy requirement is estimated ${ }^{9}$ to be $26.6 \times 10^{6} \mathrm{Btu} / \mathrm{hr}$. Thus, for the AC process the required energy consumption and capital cost are both 1arge.

Water quenching of the melt, as is prescribed for this method, requires the use of large amounts of water to prevent vapor explosions. The use of coa1 in the reducer has not yet been demonstrated. If coal or coke containing ash were used in the reducing step instead of low-ash petroleum coke, an additiona1 $1-3 \%$ of the potassium would be lost as unextractable silicates. The use of molten salt in the reducer results in serious materials problems.

\section{Modified Tampella Process}

The Tampella process, ${ }^{5}$ as developed and commercially tested for the sodium system in the paper and pulp industry, Involves nnly the carbonation of sulfide. To employ a modified version for a seed-regeneration system, an appropriate step to reduce $\mathrm{K}_{2} \mathrm{SO}_{4}$ to $\mathrm{K}_{2} \mathrm{~S}$ is thus required. The chemical reactions involved in the modified version for the potassium system are the following:

In reducer

$$
\mathrm{K}_{2} \mathrm{SO}_{4}+2 \mathrm{C} \rightarrow \mathrm{K}_{2} \mathrm{~S}+2 \mathrm{CO}_{2}
$$

In precarbonator

$$
2 \mathrm{~K}_{2} \mathrm{~S}+\mathrm{CO}_{2}+\mathrm{H}_{2} \mathrm{O} \rightarrow \mathrm{K}_{2} \mathrm{CO}_{3}+2 \mathrm{KHS}
$$

In stripper

$$
\mathrm{KHS}+\mathrm{KHCO}_{3}+\mathrm{K}_{2} \mathrm{CO}_{3}+\mathrm{H}_{2} \mathrm{~S}
$$




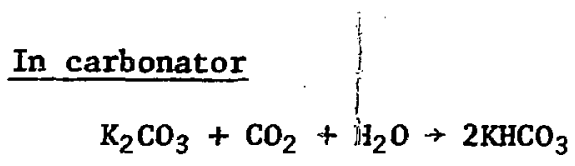

With the addition of a reduction step, the Tampella process is quite similar to the AC process. The main difference is that the AC process uses the same unit for the stripping of $\mathrm{H}_{2} \mathrm{~S}$ and formation of potassium carbonate and bicarbonate, whereas the Tampella process has a separate section for stripping of $\mathrm{H}_{2} \mathrm{~S}$ and formation of potassium bicarbonate. Consequently, the $\mathrm{H}_{2} \mathrm{~S}$ concentration in the effluents from the $\mathrm{AC}$ process is much lower than in the Tampella process.

For the reduction step, the paper and pulp industry employs a kraft or similar type of furnace, into which spent sodium sulfite liquor (also called black liquor) is blown through a series of spray nozzles. To buri lignins contained in this liquor, air is introduced at various levels inside the furnace. Sodium salts coming out of the nozzles solidify on the opposite walls where the reduction of sodium sulfite and sodium sulfate to sodium sulfide takes place. Carbon from the lignins serves as the reducing agent. The reduced mass slumps slowly to the bottom of the surface, where it is collected in the molten condition and then removed. Thus, in the paper and pulp industry, the reducing agent, the heat source, and the material to be reduced are all present in one stream. In the MID system, the material to be reduced and the reducing agent are not necessarily present in the same stream. Most likely, coal or coke will be preferred to reduce $\mathrm{K}_{2} \mathrm{SO}_{4}$ to $\mathrm{K}_{2} \mathrm{~S}$; therefore, a different furnace design from that of the kraft furnace may be required. In a blast furnace concept, coal/coke along with solid or molten $\mathrm{K}_{2} \mathrm{SO}_{4}$ would be fed to the top of a shaft furnace; an air blast would be introduced into the bottom of the shaft through suitable tuyeres, and molten slag and $\mathrm{K}_{2} \mathrm{~S}$ would be withdrawn from the bottom. In a spray burner concept, as in the kraft furnace, finely ground coal/coke would be mixed with molten $\mathrm{K}_{2} \mathrm{SO}_{4}$ (or with a saturated aqueous solution of $\mathrm{K}_{2} \mathrm{SO}_{4}$ ) and blown into the furnace through a serfes of spray nozzlus. Alternatively, powdered carbon and $\mathrm{K}_{2} \mathrm{SO}_{4}$ could be blown through separate nozzles, with the two streams iminging on each other. A third concept would be to use a two-compartmen,, molten-salt reactor, as was used in an earlier version of the AC process.?

No kinetic or experimental data are available for the potassium system. If coal or coke was used in the reduction furnace to reduce $\mathrm{K}_{2} \mathrm{SO}_{4}$ in addition to normal system losses, some additional potassium would be lost because of the reaction with ash constituents, such as $\mathrm{SiO}_{2}, \mathrm{Al}_{2} \mathrm{O}_{3}$, etc. As in the $\mathrm{AC}$ process, the materials problems with the potassium system could be very significant for the reduction furnace. Problems of vapor explosions in water-quenching of the melt also exist in the Modified Tampella process.

\section{Markant Process}

The chemtcal reactions involved in the Markant process ${ }^{6}$ are as follows:

$$
\begin{aligned}
& \mathrm{K}_{2} \mathrm{SO}_{4} \text { (slurried in oil) }+2 \mathrm{C} \stackrel{\text { incinerate }}{\longrightarrow} \mathrm{K}_{2} \mathrm{~S}+2 \mathrm{CO}_{2}\left(+\mathrm{SO}_{2}\right) \\
& \mathrm{K}_{2} \mathrm{~S}\left(+\mathrm{K}_{2} \mathrm{CO}_{3} \text {, as a smelt }\right)+\mathrm{ZnO}+\mathrm{H}_{2} \mathrm{O} \stackrel{\mathrm{ag}}{\longrightarrow} \mathrm{ZnS}+2 \mathrm{KOH}\left(+\mathrm{K}_{2} \mathrm{CO}_{3}\right)
\end{aligned}
$$




$$
\begin{aligned}
& 2 \mathrm{ZnS}+3 \mathrm{O}_{2} \stackrel{\text { roast }}{\longrightarrow} 2 \mathrm{ZnO}+2 \mathrm{SO}_{2} \\
& 2 \mathrm{KOH}+\mathrm{CO}_{2} \stackrel{\text { aq, }}{\longrightarrow} \mathrm{K}_{2} \mathrm{CO}_{3}+\mathrm{H}_{2} \mathrm{O}
\end{aligned}
$$

This process has not been completely tested or developed. Sufficient conversion of $\mathrm{K}_{2} \mathrm{~S}$ to $\mathrm{KOH}$, and complete separation of zinc and potassium may be problems. The sulfides of potassium and zinc are known ${ }^{13}$ to form a complex, $\mathrm{K}_{2} \mathrm{~s} \cdot 3 \mathrm{ZnS}$, which on exposure to air forms potassium thlosulfate. Thus, In the second step of the process, some $\mathrm{K}_{2} \mathrm{~S}$ may be lost by this mechanism. Also, it has been reported 14 that $\mathrm{ZnO}$, after regeneration form $\mathrm{ZnS}$, does not regain its original chemical reactivity. If coal or coke is used instead of oil as a heat source and reducing agent, the ash constituents such as $\mathrm{SiO}_{2}, \mathrm{Al}_{2} \mathrm{O}_{3}$, $\mathrm{CaO}$, etc. may react with $\mathrm{K}_{2} \mathrm{SO}_{4}$ causing an additional seed loss. The chenfical reaction for reduction of $\mathrm{K}_{2} \mathrm{SO}_{4}$ to $\mathrm{K}_{2} \mathrm{~S}$ is the same as that of the $\mathrm{AC}$ and Tampeila processes, although the conditions for the reduction are considerably different. However, the Tampella or AC process does not require an additive such as $\mathrm{ZnO}$ for the sulfur-separation step. The Markant process seems to have no clear advantage over the Tampella or the AC process, except perhaps a higher concentration of sulfur in the gaseous effluent. In the Markant process, most of the sulfur is released in the form of $\mathrm{SO}_{2}$ while in the AC and Tampella process it is in the form of $\mathrm{H}_{2} \mathrm{~S}$.

\section{E. Engel-Precht Process}

The chemical reactions in the Engel-Precht process ${ }^{7}$ are as follows:

$$
\begin{aligned}
& \mathrm{K}_{2} \mathrm{SO}_{4}+3 \mathrm{MgCO}_{3} \cdot 3 \mathrm{H}_{2} \mathrm{O}+\mathrm{CO}_{2} \frac{\mathrm{aq} \cdot 18-25^{\circ} \mathrm{C}}{1-2 \mathrm{~atm}} 2 \mathrm{MgCO}_{3} \cdot \mathrm{KHCO}_{3} \cdot 4 \mathrm{H}_{2} \mathrm{O}+\mathrm{MgSO}_{4} \\
& \text { (ínsoluble) (soluble) }
\end{aligned}
$$

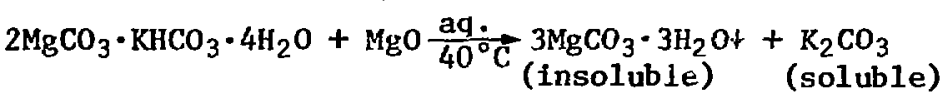

This process has been used industrially in Germany for many years to produce $\mathrm{K}_{2} \mathrm{CO}_{3}$ from $\mathrm{KCl}$ or $\mathrm{K}_{2} \mathrm{SO}_{4}$. The main advantage is that the process is not energy intensive; it consumes fuel only to produce MgO (probably from dolomite) and needs very small amounts of heat for the second step. However, the theoretical overall conversion of $\mathrm{K}_{2} \mathrm{SO}_{4}$ to $\mathrm{K}_{2} \mathrm{CO}_{3}$ is between 50 and $70 \%$ (which is insufficient for high-sulfur coal), and the loss of potassium in liquid waste strearn is about $5 \%$. Unless $\mathrm{MgSO}_{4}$ can be utilized for its chemical value, $\mathrm{MgSO}_{4}$ presents a waste-disposal problem because it is water-soluble, and thus can be leached by groundwater.

\section{F. Formate Processes}

The chemical reactions for the Formate process ${ }^{8-10}$ are as follows:

$$
\begin{aligned}
& \mathrm{K}_{2} \mathrm{SO}_{4}+\mathrm{Ca}(\mathrm{OH})_{2}+2 \mathrm{CO} \frac{200^{\circ} \mathrm{C}}{30 \text { atm }} 2 \mathrm{HCOOK}+\underset{\left(\mathrm{CaSO} \mathrm{S}_{4}+\right.}{\left.\mathrm{Sol}_{+}\right)} \\
& 2 \mathrm{HCOOK}+\mathrm{O}_{2} \frac{\text { calcined }}{700-750^{\circ} \mathrm{C}} \mathrm{K}_{2} \mathrm{CO}_{3}+\mathrm{CO}_{2}+\mathrm{H}_{2} \mathrm{O}
\end{aligned}
$$


This process was used industrially in Germany until at least the beginning of World War II. Some $\mathrm{K}_{2} \mathrm{SO}_{4}$ may be lost as $\mathrm{CaSO}_{4} \cdot \mathrm{K}_{2} \mathrm{SO}_{4} \cdot \mathrm{H}_{2} \mathrm{O}$ (syngenite) or as $5 \mathrm{CaSC}_{4} \cdot \mathrm{K}_{2} \mathrm{SO}_{4} \cdot \mathrm{H}_{2} \mathrm{O}$. According to a recent $A V C O$ report, 9 sulfur recovered in the form of zypsum $\left(\mathrm{CaSO}_{4} \cdot 2 \mathrm{H}_{2} \mathrm{O}\right)$ in this process is gel-like and difficult to filter. On the basis of work done on the sodium system, 15 the AVCo report recommends solving the filtration problem by recycling sufficient formate solution so that the potassium sulfate solution entering the reactor will contain at least $10 \%$ formate. Most of the information about the formate process is patented and not available in open literature. However, from the available information, it is evident that the process can provide $\mathrm{K}_{2} \mathrm{CO}_{3}$ of $99 \%$ purity with overall conversion of $\mathrm{K}_{2} \mathrm{SO}_{4}$ to $\mathrm{K}_{2} \mathrm{CO}_{3}$ greater than $90 \% .10$

The AVCO report ${ }^{9}$ also points out that the second step of the process could be avolded by feeding potassium formate, as a dry powder or a concentrated solution, to the MHD combustor, with no significant penalty on plasma conductivity. By feeding the seed material to the MHD combustor as potassium formate, the oxidation step to carbonate would take place inside the combustor, and the heat of this exothermic reaction $(109.9 \mathrm{kcal} / \mathrm{nol}$ at $298 \mathrm{~K})$ would be recovered by hot combustion gases. This recovery might reduce the overall process energy requirement.

Carbon monoxide required for the Formate process is usually obtained from a coal or coke gasifier. According to the AVCo report, ${ }^{9}$ tarry materials and especially $\mathrm{CO}_{2}$ must be removed from the gasifier effluent before it enters the reactor. Otherwtse, the $\mathrm{CO}_{2}$ reacts with lime to form $\mathrm{CaCO}_{3}$, which then causes a scaling problem in the evaporators; also, tarry materials condense on the wal.1s and affect the heat and mass transfer.

\section{G. Double Alkali/Caustlcization/Hydrated Lime Processes}

The chemical steps involved in these similar processes ${ }^{9}$ are as follows:

$$
\begin{aligned}
& \mathrm{K}_{2} \mathrm{SO}_{4}+\mathrm{Ca}(\mathrm{OH})_{2} \frac{\mathrm{a \eta} \cdot}{190^{\circ} \mathrm{C}} 2 \mathrm{KOH}+\mathrm{CaSO}_{4} \downarrow \\
& 2 \mathrm{KOH}+\mathrm{CO}_{2} \stackrel{\text { ambient temp. }}{\longrightarrow} \mathrm{K}_{2} \mathrm{CO}_{3}+\mathrm{H}_{2} \mathrm{C}
\end{aligned}
$$

Owing to the limited solubilities of calcium salts and the thermodynamic equilibrium of the system, very dilute solutions of $\mathrm{K}_{2} \mathrm{SO}_{4}$ (about $1.4 \times 10^{-2}$ mol/L) are required for greater than $75 \%$ conversion to $\mathrm{KOH}$ in the normal operating temperature range of 150 to $190^{\circ} \mathrm{C}$. Osing Illinois $\$ 6$ coal this means that subsequently about $400 \mathrm{lb}$ of water used for dilution needs to be evaporated per pound of $\mathrm{K}_{2} \mathrm{SO}_{4}$ that is processed. Some $\mathrm{K}_{2} \mathrm{SO}_{4}$ may be lost as a double salt with $\mathrm{CaSO}_{4}$. Sulfur recovered in the form of $\mathrm{CaSO}_{4} \cdot 2 \mathrm{H}_{2} \mathrm{O} \mathrm{n} n \mathrm{ses}$ a waste-disposal problem. Calclum remaining in solution with the potassium can cause scaling problems in the evaporator due to formation of $\mathrm{CaCO}_{3}$.

\section{PROCESS CONSIDERATIONS}

Each of the seven processes described above was assessed using the conditions and assumptions described previously in Section I. 
The Enge1-Precht process, although having an advantage of being a lowtemperature process was eliminated fromi consideration for several reasons. First, according to the ground rules, sulfur from $\mathrm{K}_{2} \mathrm{SO}_{4}$ was to be recovered in the form of elemental sulfur and no sulfur throw-away processes were to be considered. Other reasons were as follows: (1) theoretical conversion of $\mathrm{K}_{2} \mathrm{SO}_{4}$ to $\mathrm{K}_{2} \mathrm{CO}_{3}$ is only $50-70 \%$, which is inadequate for Illinois coal; (2) about $5 \% \mathrm{~K}_{2} \mathrm{SO}_{4}$ could be lorst with the $\mathrm{MgSO}_{4}$ solution in the waste stream, and (3) $\mathrm{MgSO}_{4}$ presents a waste-disposal problem because it is water-soluble and therefore can be leached by groundwater.

The Formate process was not considered further because it also did not meet the ground rules of sulfur recovery. This process also has the disadvantage that it requires pure co to prevent scaling in the evaporators. Consequently, extensive purification is required to remove $\mathrm{CO}_{2}$ and tarry materials from the gasifier effluent.

The Double Alkali process also did not meet the requirement of sulfur recovery. An additional disadvantage is the necessity for using very dilute solutions of $\mathrm{K}_{2} \mathrm{SO}_{4}$ to achieve the necessary conversion to hydroxide. As mentioned earlier, to achieve $75 \%$ (or greater) conversion to $\mathrm{KOH}$ would require the evaporation of about 400 pounds of water for each pound of $\mathrm{K}_{2} \mathrm{SO}_{4}$ used.

The Markant process qualified for a more extensive analysis. The first step in the Markant process, namely, the reduction of $\mathrm{K}_{2} \mathrm{SO}_{4}$ to $\mathrm{K}_{2} \mathrm{~S}$, is very similar to the reduction steps in the modified Tampella and the AC processes. However, with the present oil shortage, it may not be economical nor possible to feed $\mathrm{K}_{2} \mathrm{SO}_{4}$ to the furnace in a form of an oil slurry, as the Markant process requires. Once the reduction melt of $\mathrm{K}_{2} \mathrm{~S}$ is formed, the subsequent carbonation to $\mathrm{K}_{2} \mathrm{CO}_{3}$ can easily be carried out following the established techniques of the Tampe1la process. The use of $\mathrm{ZnO}$ to scavenge sulfur out of $\mathrm{K}_{2} \mathrm{~S}$ may subsequently give concentrated $\mathrm{SO}_{2}$ by roasting of $\mathrm{ZnS}$; however, this procedure would have to be developed and demonstrated. Very little is known about the double salt, $\mathrm{K}_{2} \mathrm{~S} \cdot 3 \mathrm{ZnS}$; therefore, a detailed study would be required to establish conditions under which double salt formation can be avoided or minimized. On air oxidation, this complex forms thiosulfates and thus reduces the overall conversion from sulfate to carbonate. Thus, it is doubtful that the Markant process can achieve adequate conversion of $\mathrm{K}_{2} \mathrm{~S}$ and sufficient recovery of $\mathrm{ZnO}$. Another problem is that upon regeneration $\mathrm{ZnO}$ does not completely regain its original chemical reactivity.

The differences between the modified Tampella process and the AC process are minor. In the AC process, because the stripping and carbonation steps are carried out in a singrle unit, the concentration of $\mathrm{H}_{2} \mathrm{~S}$ in the effluents is lower than in the Tampella process. The AC process has been tested so far only on a pilot-plant scale for a sodium system. Although most of the components in the AC process have been tested separately, the integrated process, as an entire system, has not yet been tested. Also, the use of coal to reduce $\mathrm{Na}_{2} \mathrm{SO}_{4}$ to $\mathrm{Na}_{2} \mathrm{~S}$ has not yet been demcistrated. Because very little information on the $\mathrm{AC}$ process is available in the literature, the operating and design conditions for the various components are not known. On the other hand, the Tampella process has been demonstrated to be a practical system for sodium compounds by the paper and pulp industry. Available information on the operating and design conditions for the Tampella process, although limited, was considered to be helpful in designing a system for potassium; therefore, 
a decision was made to carry out a detailed analysis based on the modified Tampe1la process. Information on the extensive operation of kraft-type recovery furnaces should also provide valuable input for the designi of a reduction furnace for the seed regeneration system.

Further information on the Aqueous Carbonate process may become avallable in the future, as the result of a planned project of the Environmental Protection Agency (EPA) and Empire State Electric Energy Research Corporation (ESEERC0). 15a These organizations are jointly sponsoring a 100-MW demonstration plant to be operated at the Huntley generating station of Niagara Mohawk Power Corporation (NMPC) on one of their coal-fired boilers; the AC process will be tested as part of the flue-gas desulfurization process to determine its capability for regenerating the $\mathrm{SO}_{2}$-absorbing media. If the results of this demonstration are favorable it may be possible in the future to direct the developmental program on seed regeneration toward this process with little difficulty.

Of the various seed regenerating processes, the Westinghouse report ${ }^{12}$ recommended the PERC process on the basis of three features: (1) minimum recycle of water with the regenerated seed, (2) minimun energy requirements, and (3) minimum capital requirements. In their opinion, the PERC process is relatively easy to control. In combination with the Claus or Stretford process, the PERC process also provides the sulfur in the desirable form of eiemental sulfur. However, the PERC process has many disadvantages, such as apparently poor gas utilization, three high-temperature operations (coal gasification, seed reduction and seed carbonation), and unknown kinetics. From equilibrium calculations, better gas utilization seems possible and, with proper reactor design, gas recycle, and stage-wise operation, gas utilization may be improved. Since experimental information about this process is incomplete, it should remain under consideration as a possible seed regeneration process until more engineering data are obtained.

The evaluations of the Tampeila and PERC processes were conducted on the basis of process feasibility and energy usage only. Cost analyses were not included because data for making reasonable estimates were not available. Although the Tampella process is a proven commercial process it has been used only for sodium salts. The PERC process has not been developed beyond the laboratory stage, and no reliable kinetic data are available. Without these data the principal items or equipment for a seed-regeneration system ( $e_{. g}$, , the reducer and regenerator) cannot be designed nor can their cost be estimated. Moreover, corrosion and erosion by hi.gh-temperature potassium salts may also affect construction costs. We have included pertinent results of other published economic analyses, however, and a brief discussion of these is presented.

\section{SULFUR-RECOVERY PROCESSES}

Effluents from seed-regeneration systems based on the PERC, Tampella, and $\mathrm{AC}$ processes will contain $\mathrm{H}_{2} \mathrm{~S}$ and small amounts of $\mathrm{COS}, \mathrm{CS}_{2}, \mathrm{SO}_{2}, \mathrm{~S}_{2}$, etc. Effluents from the Markant process will contain mainly $\mathrm{SO}_{2}$. Environmental and safety standards require that most of these compounds be removed from waste gas streams prior to discharge. Varlous sulfur recovery processes are described in the literature; snme are designed to operate on the tail gases 
(1-3\%, $\mathrm{H}_{2} \mathrm{~S}$ ) and some on the concentrated feed $\left(5-20 \% \mathrm{H}_{2} \mathrm{~S}\right)$. The claus, Trentham Trencor-M, and Stretford processes are described as being capable of handling concentrated feed. The Beavon, Scot, Wellman-Lord, IFP, Cold Bed Absorption (CBA), and Sulfreen processes are described as operating malily on the low-sulfur tail gases from the Claus plant.

In reference to seed regeneration systems, interest will be mainly on processes capable of handling concentrated $\mathrm{H}_{2} \mathrm{~S}$ feeds. Because the Trentham Trencor-M process has not yet been demonstrated successfully on a commercial unit, only the Claus and Stretford processes were considered.

Of the processes capable of recovering sulfur from $\mathrm{SO}_{2}$, the Resox pracess ${ }^{16}$ has been well developed. In this process, in the presence of steam, $\mathrm{SO}_{2}$ is reduced by coal (preferably anthracite coal) at about 1100-1500 $\mathrm{F}$ yielding $\mathrm{CO}_{2}$ and sulfur. This process can handle $\mathrm{SO}_{2}$ concentrations from 2 to 20 vol $\%$. It can tolerate residual fly-ash and elininates gas drying. The absence of catalysts in this process sidesteps the concern over trace contaminants. Furthermore, the Resox process offers an interesting flexibility of recovering. sulfur as $\mathrm{H}_{2} \mathrm{~S}$ rather than an elemental sulfur-rich stream. Because of the Incomplete development of the Markant process, a suj.fur recovery step appropriate to other steps in the process has not yet been tested. However, in the future, If more work is to be conducted on the Markant process, then the Resox process is certainly a strong candidate for sulfur recovery.

\section{A. Claus Process}

The Claus sulfur-recovery process ${ }^{11}$ is a multiple-stage, catalytic process used for converting $\mathrm{H}_{2} \mathrm{~S}$ to elemental sulfur by following the claus reaction:

$$
2 \mathrm{H}_{2} \mathrm{~S}+\mathrm{SO}_{2} \nsucceq 3 \mathrm{~S}+\mathrm{H}_{2} \mathrm{O}
$$

The sulfur dioxide required for the reaction is produced by burning about one-third of the $\mathrm{H}_{2} \mathrm{~S}$ present in a furnace $\left(\mathrm{H}_{2} \mathrm{~S}+3 / 2 \mathrm{O}_{2} \rightarrow \mathrm{SO}_{2}+\mathrm{H}_{2} \mathrm{O}\right)$. The feed to a conventional Claus plant should contain at least $20 \% \mathrm{H}_{2} \mathrm{~S}$; below this level it becomes impossible to maintain a stable flame temperature in the furnace. For acidic gases containing about 15 to $20 \% \mathrm{H}_{2} \mathrm{~S}$, additional heat can be added to the system by preheating furnace combustion air to about $700^{\circ} \mathrm{F}$ $\left(370^{\circ} \mathrm{C}\right)$. At $\mathrm{H}_{2} \mathrm{~S}$ concentrations below $15 \%$, some of the product sulfur can be recycled and burned in the furnace; this step extends the range of $\mathrm{H}_{2} \mathrm{~S}$ concentrations that can be handled in Claus feed plants to feeds down to about $5 \%$.

The most severe limitation on Claus performance is the presence of traces of organic sulfur compounds, $\mathrm{CO}_{2}$, hydrocarbons, heavy organics, $\mathrm{NH}_{3}$, and cyanides. Usually these compounds either reduce the catalyst activity by fouling, or dilute the $\mathrm{H}_{2} \mathrm{~S}$ concentration in the feed, thereby also reducing the sulfur recovery. According to EPA policy on sulfur-emission control, the Claus process alone is not acceptable. To increase the sulfur-removal efficiency from $92-96 \%$ (possible with three catalytic stages in Claus process) to about $99.8 \%$ (corresponds to about 200-300 ppm in the off-gas), a prosess for treating tail-gas is required. However, such a process can account for about two-thirds of the cost of the total sulfur-recovery system and a significant portion of the energy requirements. 


\section{B. Stretforả Process}

In this process, $11 \mathrm{a}$ the sulfur-bearing gas is fed to an absorber where $\mathrm{H}_{2} \mathrm{~S}$ is reacted as follows:

$$
\mathrm{Na}_{2} \mathrm{CO}_{3}+\mathrm{H}_{2} \mathrm{~S} \& \mathrm{NaHS}+\mathrm{NaHCO}_{3}
$$

In the bottom of the absorber, sodium vanadate $\left(\mathrm{NaVO}_{3}\right)$ oxidizes bisulfide to elemental sulfur as follows:

$$
\mathrm{NaHS}+2 \mathrm{NaVO}_{3}+1 / 2 \mathrm{H}_{2} \mathrm{O} \rightleftarrows 1 / 2 \mathrm{Na}_{2} \mathrm{~V}_{4} \mathrm{O}_{9}+2 \mathrm{NaOH}+\mathrm{S}
$$

Vanadium(IV) is reoxidized to vanadium(V) with anthraquinone disulfonic acid (ADA), as follows:

$$
\mathrm{Na}_{2} \mathrm{~V}_{4} \mathrm{O}_{9}+2 \mathrm{NaOH}+\mathrm{H}_{2} \mathrm{O}+2 \mathrm{ADA} \rightleftarrows 4 \mathrm{NaVO}_{3}+2 \mathrm{ADA} \text { (reduced) }
$$

The mixture of sulfur and the solution containing sodium-vanadium salts is mixed with air where ADA is reoxidized:

$$
2 \mathrm{ADA} \text { (reduced) }+\mathrm{O}_{2} \rightleftarrows 2 \mathrm{ADA}
$$

In the absorber of the Stretford process redwood slats are used to provide good contact of the gases containing $\mathrm{H}_{2} \mathrm{~S}$ with the $\mathrm{Na}_{2} \mathrm{CO}_{3}$ solution. Above concentrations of about $5 \% \mathrm{H}_{2} \mathrm{~S}$, some units are reported to experience plugging with sulfur. Recent developments indicate that a venturi scrubber can be used for feeds above the $5 \% \mathrm{H}_{2} \mathrm{~S}$ level.

Part of the recovered sulfur forms sodium thiosulfate, which is not regenerable and therefore has to be purged from the system to maintain solution activity. Since the cost of the vanadium salts in the Stretford solution is high, this purge must be minimized. As in the claus process, the performance of the Stretford process is also affected adversely by organic sulfur compounds (such as $\mathrm{COS}, \mathrm{CS}_{2}$ ), $\mathrm{CO}_{2}$, hydrocarbons, and cyanides.

It is claimed by the developer of the process that under ideal conditions the $\mathrm{H}_{2} \mathrm{~S}$ level in the tail gases can be reduced to $10 \mathrm{ppm}$ with the Stretford process. However, a realistic goal is set around $100 \mathrm{ppm}$, which is well within EPA limits.

Because the Stretford process does not need a tail-gas clean-up system (as in the Claus process) and is capable of handling $\mathrm{H}_{2} \mathrm{~S}$ concentrations in the feed material ranging from 5-20\%, only the Stretford process for sulfur recovery was considered in the analysis that foilows.

\section{SEED RECOVERY}

Most of the seed (primarily as $\mathrm{K}_{2} \mathrm{SO}_{4}$ ) that will be collected in the various downstream components and electrostatic precipitators will be contaminated with some ash. It would obviously be advantageous if, in the seed-regeneration process, small amounts of $\mathrm{Al}_{2} \mathrm{O}_{3}, \mathrm{SiO}_{2}, \mathrm{Fe}_{2} \mathrm{O}_{3}$, and $\mathrm{CaO}$, etc. mixed with the $\mathrm{K}_{2} \mathrm{SO}_{4}$ did not affect the conversion to carbonate nor interfere with the conbustor and channel operations. However, since none of the candidate processes 
have demonstrated this capability, it was assumed in the analyses of the PERC and lampe1la processes that separation from most of these insolubles could be achieved by leaching of $\mathrm{K}_{2} \mathrm{SO}_{4}\left(+\mathrm{K}_{2} \mathrm{CO}_{3}\right)$ with hot water. A schematic drawing of this seed-recovery step is shown in Fig. 1 .

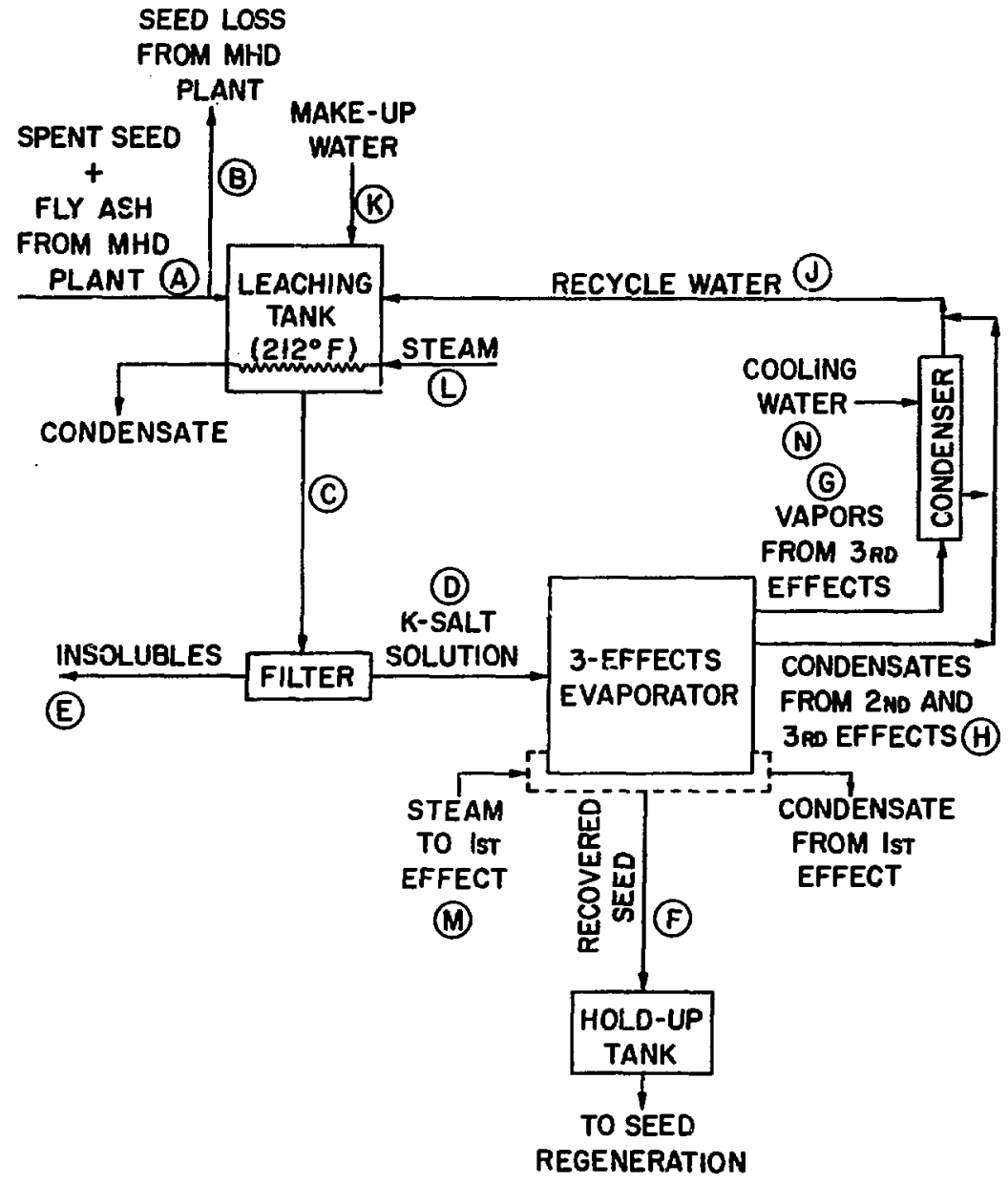

F1g. 1. Schematic of Seed-Recovery Process $(A, B, C$, etc. refer to entries in Table 3.) 
According to the basic ground rules, the collected mixture of spent seed and fly-ash would contain 95 wt $\% \mathrm{~K}_{2} \mathrm{SO}_{4}$ plus $\mathrm{K}_{2} \mathrm{CO}_{3}$, contaninated with 5 wt \% fly-ash. Most of the fly-ash portion is assumed to consist of insolubles.

The minimum potassium recovery specified is $95 \%$. The $5 \%$ loss of potassium was distributed arbitrarily as follows:

1. $2 \%$ lost in MHD plant.

2. $2 \%$ lost in seed-recovery step as insoluble and unextractable potassium aluminosilicates (includes inefficiency of extraction, filter loss, etc.).

3. $1 \%$ lost in seed-regeneration step (includes inefficiency of regentration, loss as unconvertible, soluble potassium silicates, etc.).

In the present analysis, it was assumed that a seed recovery step is required for both the Tampella and PERC processes. In the future, it may be possible to avoid a seed recovery step if development work shows that the small amount of ash does not affect recovery of sulfur from $\mathrm{K}_{2} \mathrm{SO}_{4}$.

Simflarly, in the future, it may be possible that in one or both processes the feed material for the reduction step can be either solid or molten sulfate. However, in the present analysis, the feed was assumed to be a solid mixture of $\mathrm{K}_{2} \mathrm{SO}_{4}$ and $\mathrm{K}_{2} \mathrm{CO}_{3}$ containing a small amount (about 10 wt \%) of water.

Other Important assumptions involved in the analysis of the seed recovery scheme are the following:

1. Because of the high molar ratio of $\mathrm{K}_{2} \mathrm{SO}_{4}$ to $\mathrm{K}_{2} \mathrm{CO}_{3}$ in the spent seed, the entire mixture may be assumed to follow the solubility of pure $\mathrm{K}_{2} \mathrm{SO}_{4}$.

2. The extraction efficiency of spent seed with hot water is $99 \%$.

3. Thermophysical properties of water were used for the solution and slurry containing potassium salts. Thus, property changes such as elevation in bolling point, differences in heat capacity, etc. wer:not considered.

4. Various heat losses were neglected.

5. The heat of solution of $\mathrm{K}_{2} \mathrm{SO}_{4}$ was taken for the case of a very dilute solution.

6. Auxiliary power required to run various pumps and other electrical units was assumed to be about $10 \%$ of the total requirement for steam or other forms of energy.

The seed-recovery scheme shown in Fig. 1 and the assumptions outlined above were used to calculate mass and heat balances around major components. The calculated compositions of the various streams, as well as the energy requirements for the major components, are given in Table 3 .

In the detailed analyses of seed-regeneration processes described in the following sections, the stream exiting from the seed-recovery hold-up tank served as the input stream for both the PERC and Tampella processes. 
Table 3. Flow Chart for Seed-Recovery System

Basis: 1000 MWt plant

Illinois $\# 6$ coal feeding rate $=270,0001 \mathrm{~b} / \mathrm{hr}$

Seed feed rate to MHD plant $=46,800 \mathrm{lb} / \mathrm{hr}$ (85 wt $\% \mathrm{~K}_{2} \mathrm{CO}_{3}$ )

\begin{tabular}{|c|c|c|c|c|c|c|c|c|}
\hline \multirow[b]{2}{*}{$\begin{array}{l}\text { Process } \\
\text { Stream }^{\mathrm{a}}\end{array}$} & \multicolumn{4}{|c|}{ Stream Components, $1 \mathrm{~b} / \mathrm{hr}$} & \multirow[b]{2}{*}{$\begin{array}{l}\text { Steam, } \\
\mathrm{lb} / \mathrm{hr}\end{array}$} & \multirow{2}{*}{$\begin{array}{l}\text { Cooling } \\
\text { Water, } \\
\text { lb } / \mathrm{hr}\end{array}$} & \multirow[b]{2}{*}{$\underset{{ }_{F}}{\text { Temp. }}$} & \multirow[b]{2}{*}{$\begin{array}{l}\text { Enthalpy, } \\
10^{6} \mathrm{Btu} / \mathrm{hr}\end{array}$} \\
\hline & $\mathrm{K}_{2} \mathrm{SO}_{4}$ & $\mathrm{~K}_{2} \mathrm{CO}_{3}$ & Ash & $\begin{array}{l}\text { Process } \\
\text { Water }\end{array}$ & & & & \\
\hline A & 52,700 & 3,600 & 2,960 & - & - & - & 60 & 0.3 \\
\hline B & 1,050 & 72 & - & -- & - & - & - & -- \\
\hline C & 51,600 & 3,550 & 2,960 & 224,000 & - & - & 212 & 42.4 \\
\hline D & 50,600 & 3,480 & 30 & 224,000 & - & - & 212 & 50.1 \\
\hline $\mathbf{E}$ & 1,050 & 72 & 2,930 & - & - & - & - & - \\
\hline F & 50,600 & 3,480 & 30 & 6,010 & -- & - & 120 & 1.5 \\
\hline $\mathbf{G}$ & - & - & -- & 79,400 & -- & - & 120 & 88.5 \\
\hline${ }^{\mathrm{b}} \mathrm{H}_{2}$ & -- & -- & -- & 67,800 & -- & - & 227 & 13.2 \\
\hline${ }^{c_{H_{3}}}{ }^{H}$ & -- & -- & - & 71,200 & - & -- & 207 & 12.5 \\
\hline $\mathbf{J}$ & - & - & - & 218,000 & - & - & 182 & 32.7 \\
\hline $\mathrm{k}$ & - & - & - & 6,010 & -- & - & 60 & 0.2 \\
\hline $2^{\mathrm{d}}$ & -- & - & - & $-\infty$ & 13,400 & - & 240 & 15.6 \\
\hline $\mathrm{M}^{e}$ & - & - & - & - & 72,800 & - & 240 & 84.5 \\
\hline $\mathbf{N}$ & $-\infty$ & - & -- & -- & - & $1,360,000$ & 60 & 38.0 \\
\hline \multicolumn{9}{|c|}{ Energy Requirements, Btu/hr } \\
\hline \multicolumn{5}{|c|}{$\begin{array}{l}\text { Heat required as steam in leaching tank } \\
\text { Heat required as steam in lst effect of evaporators } \\
\text { Subtotal }\end{array}$} & $\begin{array}{l}13 \times 10^{6} \\
\frac{69 \times 10^{6}}{82 \times 10^{6}}\end{array}$ & & & \\
\hline \multicolumn{2}{|c|}{ Auxiliary } & nps, & ers, & $\begin{array}{l}(10 \%)_{\text {Total }} \\
\end{array}$ & $\frac{8 \times 10^{6}}{90 \times 10^{6}}$ & & & \\
\hline
\end{tabular}

\footnotetext{
aletter designations refer to callouts in F1g. 1 .

${ }^{b}$ From 2nd effect of evaporators.

From 3rd effect of evaporators.

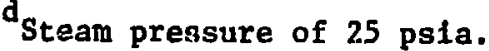

Steam pressure of 25 psia.
} 


\section{ANALYSIS OF PERC PROCESS}

A seed-regeneration scheme based on the PERC process is shown in Fig. 2. The equilibrium code developed by NASA-Lewis ${ }^{17}$ was used to calculate tne equilibrium compositions of streams fron the gasifier, reducer, and regenerator. The computer program uses the technique of free-energy minimization of the system involving given elements and thus avoids considering only one particular reaction. Thermodynamic properties for $K_{2} S$, such as free eriergy of formation as a function of temperature, were not available; however, they could be

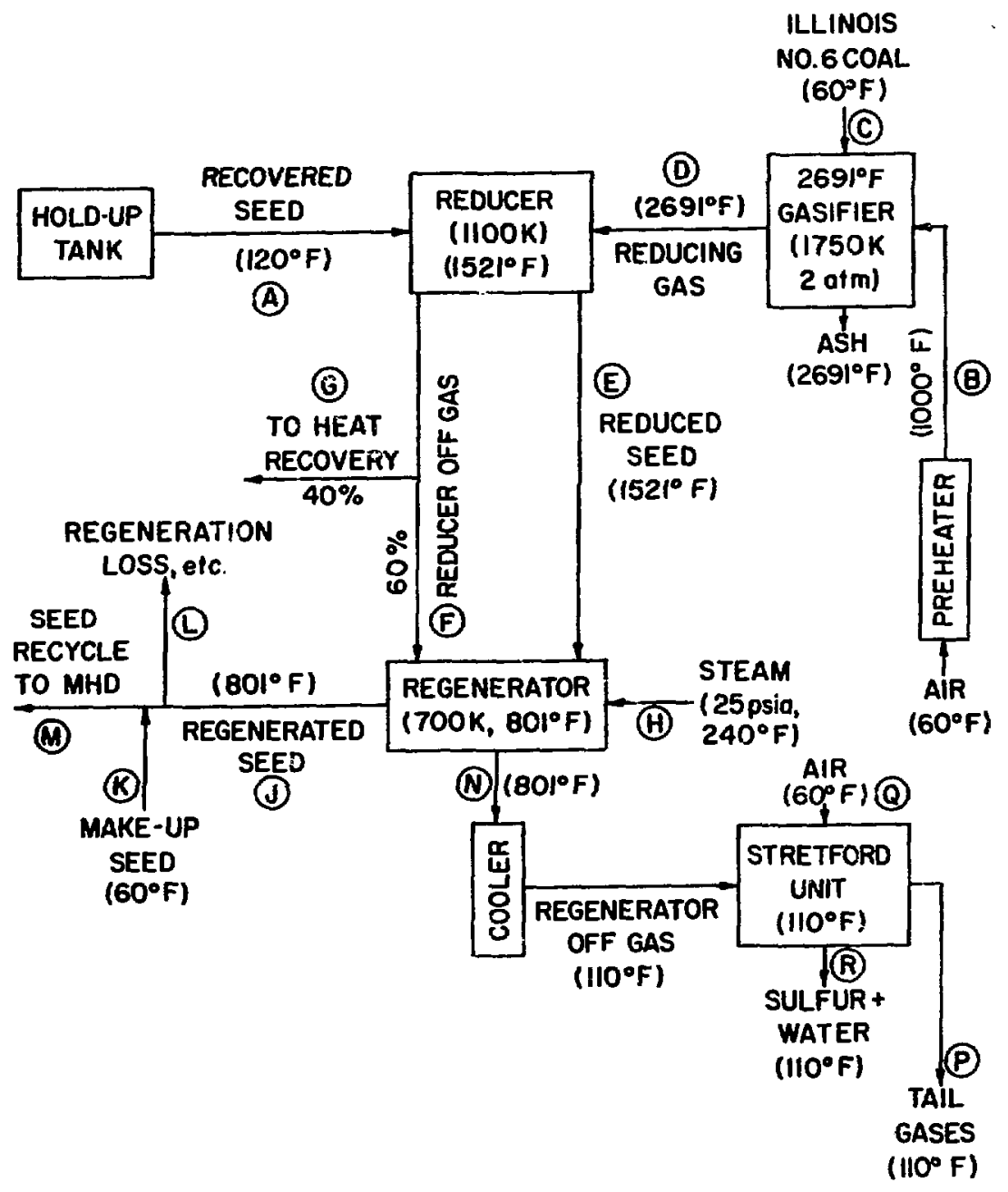

F1g. 2. Seed-Regeneration Scheme Based on the PERC Process (The letters $A, B, C$, etc. refer to process streams described in Table 4.) 
estimated from available thermophysical properties and basic principles, of thermodynamics. Some of the values for $\mathrm{K}_{2} \mathrm{~S}$ that were used are given below:

$$
\begin{aligned}
\Delta \mathrm{H}_{\mathrm{f}, 298 \mathrm{~K}}^{\circ} & =-99 \mathrm{kcal} / \mathrm{mol} \text { (Ref. 18) } \\
\Delta \mathrm{S}_{\mathrm{f}, 298 \mathrm{~K}}^{\circ} & =-11.5 \mathrm{cal} / \mathrm{mol} \cdot \mathrm{K} \text { (estimated) } \\
\Delta \mathrm{G}_{\mathrm{f}, 298 \mathrm{~K}}^{\circ} & =-95.6 \mathrm{kcal} / \mathrm{mol} \text { (estimated) } \\
C_{\mathrm{P}} & =16.78+4.74 \times 10^{-3} \mathrm{~T} \mathrm{cal} / \mathrm{mol} \cdot \mathrm{K} \text { at } 100 \leq \mathrm{T} \leq 700 \mathrm{~K}(\mathrm{Ref} .18) \\
\mathrm{C}_{\mathrm{P}} & =20.57 \mathrm{cal} / \mathrm{mol} \cdot \mathrm{K} \text { at } 800 \mathrm{~K}(\text { Ref. 18) } \\
C_{\mathrm{P}} & =25.25 \mathrm{cal} / \mathrm{mol} \cdot \mathrm{K} \text { at } 900 \mathrm{~K}(\text { Ref. 18) } \\
\mathrm{C}_{\mathrm{P}} & =35.17 \mathrm{cal} / \mathrm{mol} \cdot \mathrm{K} \text { at } 1000 \mathrm{~K} \text { (Ref. 18) }
\end{aligned}
$$

For simplifled calculation in the condensed phase, it was assumed that no interaction or solid solution between different species was possible. In addition, a computer simulation of $\mathrm{K}_{2} \mathrm{SO}_{4}$ reduction utilizing $50 \% \mathrm{CO}-50 \% \mathrm{H}_{2}$ was made with a modified version of the NASA-Lewis code, 19 which allowed for interaction among the condensed species (such as $\mathrm{K}_{2} \mathrm{SO}_{4}, \mathrm{~K}_{2} \mathrm{CO}_{3}$, and $\mathrm{K}_{2} \mathrm{~S}$ ). At $1100 \mathrm{~K}$, with no interaction, $94.8 \%$ of the $\mathrm{K}_{2} \mathrm{SO}_{4}$ was reduced; with the interaction mode, $92 \%$ was reduced. This small difference in the percent reduction of $\mathrm{K}_{2} \mathrm{SO}_{4}$ justified the assumption of no interaction among the condensed species.

In addition to the assumptions made for the seed-recovery scheme, the following rationale was used for analysis of seed regeneration and sulfur recovery:

1. The low-Btu reducing gas for the reducer is supplied by an air-blownsuspension gasifier operated at 2 atm pressure, a pressure considered adequate for transporting material through the system.

2. To obtain $85 \%$ conversion of $\mathrm{K}_{2} \mathrm{SO}_{4}$ to $\mathrm{K}_{2} \mathrm{CO}_{3}$ with I1Iinois $\# 6$ coal, the gasifier is supplied with an air/coal ratio of 3.5 and a $\mathrm{K}_{2} \mathrm{SO}_{4} / \mathrm{coal}$ ratio of 3.88. Under these conditions at 2 atm pressure, the minimum gasifier temperature at which all the carbon is converted is $1477^{\circ} \mathrm{C}\left(2691^{\circ} \mathrm{F}\right)$. The air to the gasifier is assumed to be preheated to $538^{\circ} \mathrm{C}\left(1000^{\circ} \mathrm{F}\right)$.

3. The temperature of the reducer is $827^{\circ} \mathrm{C}\left(1521^{\circ} \mathrm{F}\right)$.

4. The soluble portion of the ash from the seed recovery scheme consists of $\mathrm{Al}_{2} \mathrm{O}_{3}, \mathrm{SiO}_{2}, \mathrm{Fe}_{2} \mathrm{O}_{3}$, and $\mathrm{CaO}$, in the same proportion as in the original coal.

5. At a regenerator temperature of $427^{\circ} \mathrm{C}\left(801^{\circ} \mathrm{F}\right)$, complete conversion of $\mathrm{K}_{2} \mathrm{~S}$ to $\mathrm{K}_{2} \mathrm{CO}_{3}$ is possible. At this temperature, some $60 \%$ of the total off-gases from the reducer is mixed with a small amount of live steam in the regenerator.

6. Only the regenerator off-gases are treated in the Stretford unit for complete sulfur recovery. In the absence of ac equate data on the thermodynamics and kinetics of various reaction steps involved in the Stretford process, an overall reaction of 


$$
\mathrm{H}_{2} \mathrm{~S}+1 / 2 \mathrm{O}_{2} \rightarrow \mathrm{H}_{2} \mathrm{O}+\mathrm{S}
$$

Is considered for the mass balance calculations, and no heat balance calculations are made for this step.

7. The $1 \%$ loss of potassium that was attributed earlier to the seedregeneration scheme (due to conversion efficiency and operational loss) is assumed to be incurred equally as $\mathrm{K}_{2} \mathrm{SO}_{4}$ and $\mathrm{K}_{2} \mathrm{CO}_{3}$.

Using these assumptions, and the flow sheet shown in Fig. 2, the compositions and energy contents of the major components were calculated for the varlous streams. These calculated results are given in Tables 4 and 5 . 
Table 4. Flow Chart for Scheme Based on PERC Process

Basis: 1000 MWt plant

Illinois 非 coal feeding rate $=270,000 \mathrm{lb} / \mathrm{hr}$

Seed feed rate to MHD plant $=46,800 \mathrm{lb} / \mathrm{hr}\left(85\right.$ wt $\left.\% \mathrm{~K}_{2} \mathrm{CO}_{3}\right)$

\begin{tabular}{|c|c|c|c|c|c|c|c|c|c|c|c|c|c|c|}
\hline \multirow[b]{2}{*}{$\begin{array}{l}\text { Process } \\
\text { Stream }^{\mathrm{a}}\end{array}$} & \multicolumn{6}{|c|}{ Stream Components, $1 \mathrm{~b} / \mathrm{hr}$} & \multicolumn{6}{|c|}{ Gas Components, $1 \mathrm{~b} \cdot \mathrm{mol} / \mathrm{hr}$} & \multirow[b]{2}{*}{$\underset{{ }_{F}}{\text { Temp. }}$} & \multirow[b]{2}{*}{$\begin{array}{l}\text { Enthalpy, } \\
10^{6} \mathrm{Btu} / \mathrm{hr}\end{array}$} \\
\hline & $\mathrm{K}_{2} \mathrm{SO}_{4}$ & $\mathrm{~K}_{2} \mathrm{CO}_{3}$ & $\mathrm{~K}_{2} \mathrm{~S}$ & $\mathrm{Ash}^{\mathrm{b}}$ & $\begin{array}{l}\text { Process } \\
\text { Waterc }\end{array}$ & Sulfur & $\mathrm{CO}$ & $\mathrm{CO}_{2}$ & $\mathrm{H}_{2}$ & $\mathrm{H}_{2} \mathrm{~S}$ & $\mathrm{O}_{2}$ & $\mathrm{~N}_{2}$ & & \\
\hline A & 50,600 & 3,480 & -- & 30 & $6,010(1)$ & - & - & - & -- & -- & -- & - & 120 & 1.5 \\
\hline B & $\cdots$ & - & -- & - & -- & - & - & -- & -- & -- & 332 & 1,250 & 1,000 & 11.0 \\
\hline C & $(13,000$ & 1b/hr washe & led I11i & inois & \#6 coal) & - & -- & -- & -- & -- & $-\div$ & - & 60 & 164.0 \\
\hline D. & -- & -- & -- & - & $2(g)$ & - & 738 & 0.1 & 303 & 6.0 & - & 1,250 & 2,691 & 47.1 \\
\hline $\mathrm{E}^{\mathrm{d}}$ & 8,690 & 1,610 & 8,000 & 39 & - & -- & -- & - & -- & -- & -- & - & 1,521 & 11.4 \\
\hline $\mathbf{F}$ & -- & - & -- & - & $6,470(g)$ & -- & 30 & 427 & 25 & 1.0 & -- & 753 & 1,521 & 30.7 \\
\hline$G$ & -- & -- & -- & - & $4,320(g)$ & -- & 20 & 285 & 17 & 0.9 & - & 502 & 1,521 & 20.5 \\
\hline $\mathbf{H}$ & $(1,760$ & lb/hr live & steam & $@ 25 \mathrm{p}$ & psia) & - & - & -- & - & -- & $\cdots$ & -- & 240 & 2.0 \\
\hline $\mathrm{J}^{\mathrm{e}}$ & 7,190 & 37,800 & -- & 57 & -- & - & - & - & -- & -- & -- & -- & 801 & 6.9 \\
\hline $\mathrm{K}$ & 47 & 2,280 & -- & - & -- & - & -- & -- & -- & -- & -- & -- & 60 & -- \\
\hline L & 286 & 227 & - & - & - & - & - & - & -- & - & - & - & -- & - \\
\hline M & 6,950 & 39,900 & -- & - & -- & - & -- & -- & -- & -- & - & -- & 60 & - \\
\hline $\mathbf{N}$ & -- & - & - & - & $3,650 \quad(g)$ & - & 2 & 192 & 19 & 623 & -- & 753 & 801 & 13.2 \\
\hline $\mathbf{P}$ & -- & - & -- & - & $4,100 （ \mathrm{~g})$ & - & 2 & 193 & 19 & 0.1 & -- & 1,250 & 110 & 5.4 \\
\hline$Q$ & - & -- & -- & - & -- & $\cdots$ & - & - & -- & -- & 132 & 495 & 60 & 0.1 \\
\hline $\mathbf{R}$ & -- & -- & -- & - & $4,270(1)$ & 8,430 & -- & -- & -- & -- & -- & -- & 110 & 0.5 \\
\hline
\end{tabular}

atetter designations refer to callouts in Fig. 2.

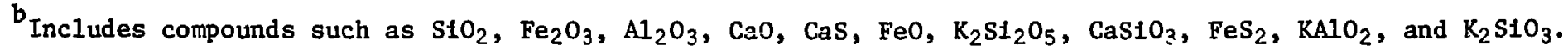

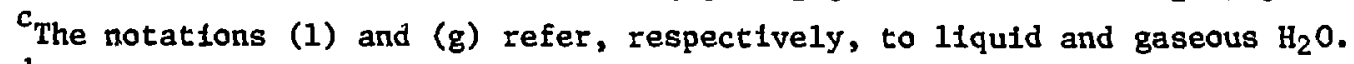

dAlso contains $4.4 \mathrm{lb} / \mathrm{hr} \mathrm{KCl}$, and $10 \mathrm{lb} / \mathrm{hr} \mathrm{KOH}$.

Also contains $3.9 \mathrm{lb} / \mathrm{hr} \mathrm{KCl}$. 
Table 5. Overall Energy Balance for Scheme Based on PERC Process

Basis: 1000 MWt plant

Illinois $\# 6$ coal feeding rate $=270,000 \mathrm{lbs} / \mathrm{hr}$

Seed feed rate to MHD plant $=46,800 \mathrm{lbs} / \mathrm{hr}$

$\left(85\right.$ wt $\% \mathrm{~K}_{2} \mathrm{CO}_{3}$ )

\begin{tabular}{|c|c|c|}
\hline & & $\begin{array}{c}\text { Energy, } \\
10^{6} \mathrm{Btu} / \mathrm{hr}\end{array}$ \\
\hline \multicolumn{3}{|l|}{ Required } \\
\hline As coal in gastfier & & 164 \\
\hline To preheat gasifier air & & 11 \\
\hline To malntain reducer temperature & & 10 \\
\hline \multirow[t]{2}{*}{ As live steam in regenerator } & & 2 \\
\hline & Subtotal & 187 \\
\hline \multirow[t]{2}{*}{ Auxiliary power $(10 \%)$} & & 19 \\
\hline & Total required & 206 \\
\hline \multicolumn{3}{|l|}{ Available } \\
\hline \multicolumn{2}{|l|}{ From reducer off-gases $\left(1521^{\circ} \mathrm{F} \rightarrow 126^{\circ} \mathrm{F}\right)$} & 17 \\
\hline \multicolumn{2}{|l|}{$\begin{array}{l}\text { From regenerator (heat of reaction, sensible } \\
\text { heat, etc.) (at } 801^{\circ} \mathrm{F} \text { ) }\end{array}$} & 39 \\
\hline \multicolumn{2}{|l|}{ From regenerator off-gases $\left(801^{\circ} \mathrm{F} \rightarrow 110^{\circ} \mathrm{F}\right)$} & 8 \\
\hline \multicolumn{2}{|l|}{ From sensible heat of regenerated seed (at $801^{\circ} \mathrm{F}$ ) } & 7 \\
\hline & Total available & 71 \\
\hline \multicolumn{3}{|l|}{ Net Required } \\
\hline \multicolumn{3}{|l|}{$\begin{aligned} \text { Net } & =(\text { total required })-(\text { total available }) \\
& =135 \times 10^{6} \mathrm{Btu} / \mathrm{hr}\end{aligned}$} \\
\hline
\end{tabular}


VII. ANALYSIS OF MODIFIED TAMPELLA PROCESS

The products from the seed-recovery step were assumed to follow the scheme shown in Fig. 3 for a modification of the Tampella process based on the use of potassium salts. Because of the lack of information on the thermodynamic properties of $\mathrm{KHS}, \mathrm{KHCO}_{3}$, etc., the NASA-Lewis computer code ${ }^{17}$ could not be used to calculate equilibrium compositions of streams coming out of the precarbonator, stripper, and carbonator; therefore, this code was used only for the reaction in the reduction furnace. scheme:

The following rationale was used for the analysis and the seed regeneration

1. For a mixture containing $85 \% \mathrm{~K}_{2} \mathrm{~S}$ and $15 \% \mathrm{~K}_{2} \mathrm{SO}_{4}$, the 1iquidus temperature is about $830^{\circ} \mathrm{C}\left(1526^{\circ} \mathrm{F}\right) .20^{\circ}$ To obtain a final melt of reduced material completely in liquid form, the temperature in the reduction furnace is kept at about $900^{\circ} \mathrm{C}\left(1550^{\circ} \mathrm{F}\right)$.

2. Based on the NASA-Lewis code, adequate reduction of $\mathrm{K}_{2} \mathrm{SO}_{4}$ (so that the overall conversion from sulfate to carbonate is about $85 \%$ ) at $1650^{\circ} \mathrm{F}$, requires about $17,600 \mathrm{lb} / \mathrm{hr}$ of Illinois $\# 6$ coal.

3. The reduced molten salts from the reduction furnace are quenched with sufficient water to avoid vapor explosions. As an alternative that eliminates the possibility of explosions and minimizes the amount of water, the melt may be gas-cooled to solidify it, crushed, and then dissolved. (This alternative was not considered in detail.)

4. Because of the low concentration of insoluble materials in the resulting liquor, a filtering step is employed instead of a conventional clarifier to remove insoluble materials such $\mathrm{Al}_{2} \mathrm{O}_{3}, \mathrm{CaS}, \mathrm{FeO}, \mathrm{K}_{2} \mathrm{Si}_{2} \mathrm{O}_{5}$, etc.

5. Based on the information from the paper and pulp industry, the precarbonator is assumed to operate at $100^{\circ} \mathrm{F}$. In the absence of adequate kinetic and thermodynamic data, it is assumed that the reaction

$$
2 \mathrm{~K}_{2} \mathrm{~S}(\mathrm{aq})+\mathrm{CO}_{2}(\mathrm{~g})+\mathrm{H}_{2} \mathrm{O}(1) \rightarrow \mathrm{K}_{2} \mathrm{CO}_{3}(\mathrm{aq})+2 \mathrm{KHS}(\mathrm{aq})
$$

goes to completion. Only one-half of the flue gas from the furnace is utilized for this operation. The other half is assumed to be utilized in the carbonator.

6. The $\mathrm{KHCO}_{3}$ required to react with KHS in the stripper is obtained by recycling a portion of the $\mathrm{K}_{2} \mathrm{CO}_{3}$ and reacting it with $\mathrm{CO}_{2}$ in the carbonator. Because of this recycle of $\mathrm{K}_{2} \mathrm{CO}_{3}$, the mass balance computations around the stripper, evaporator-separator, and carbonator are carried out in an iterative manner. The heat requirements of these units are not optimized.

7. For the reaction in the stripper, a limited amount of equilibrium data is available for a batch system involving absorption of $\mathrm{H}_{2} \mathrm{~S}$ at pressures from 0.02 to 0.7 atm in $2 \mathrm{~N} \mathrm{~K}_{2} \mathrm{CO}_{3}$ at low temperatures. ${ }^{21}$ Based on the sodium system, the stripper is maintained at $195^{\circ} \mathrm{F}$ and $0.7 \mathrm{~atm}$ total pressure. By extrapolation of equilibrium data to these conditions, it is calculated that for $\mathrm{P}_{\mathrm{H}_{2}} \mathrm{~s}$ varying from 10 to $1 \mathrm{~mm} \mathrm{Hg}$, the equilibrium conversion of KHS w111 change from 42 to 79\%. Therefore, it is assumed that in a flowing system involving nonequilibrium conditions, all of the KHS will be converted to $\mathrm{H}_{2} \mathrm{~S}$. 


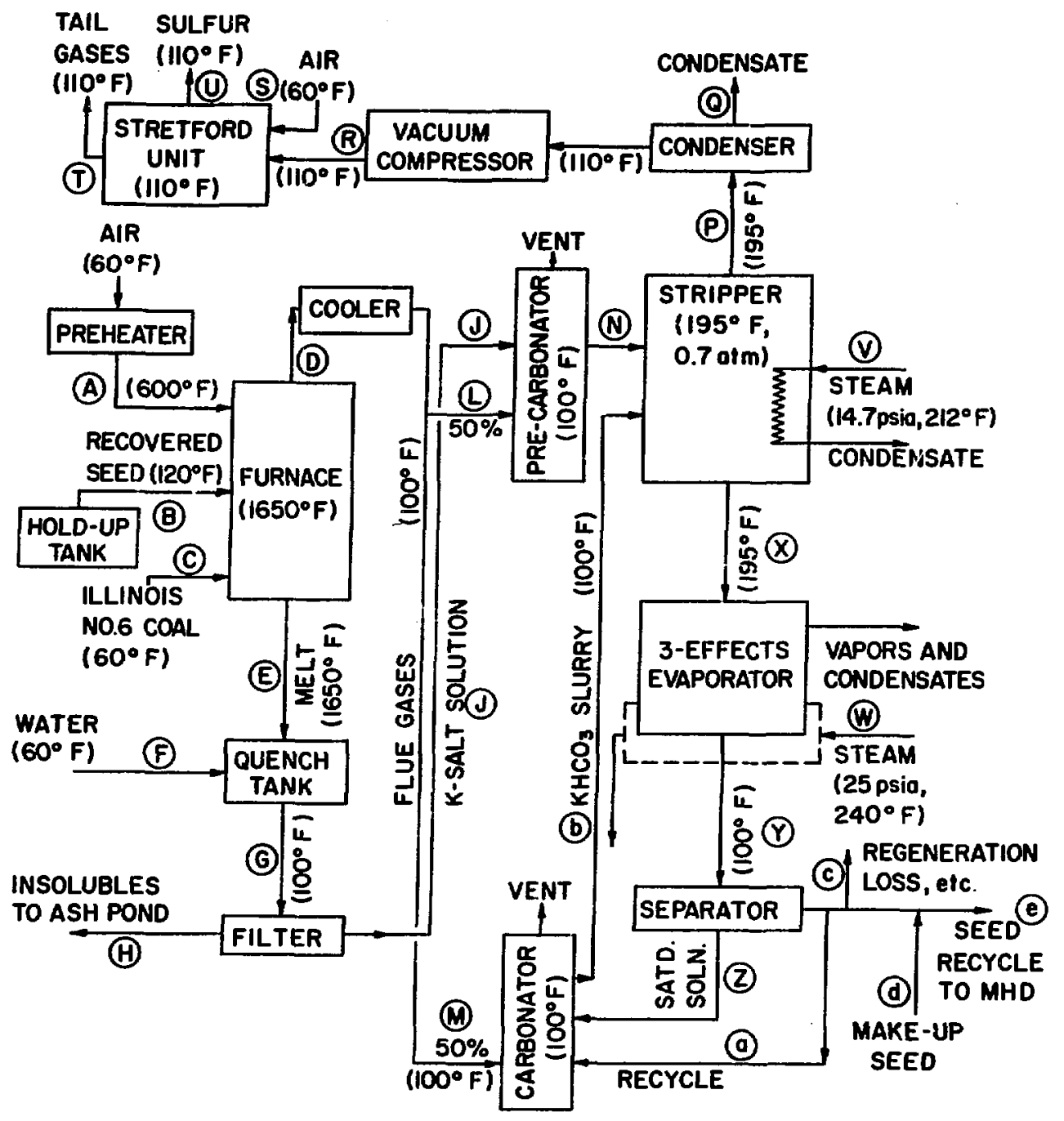

Fig. 3. Seed-Regeneration Scheme Based on Modified Tampella Process (the letters $A, B, C$, etc. refer to process streams described in Table 6)

8. To economize on steam consumption, a three-effects evaporator system is used. The third effect can very well be a combined crystallizer-evaporator system. Options for separation in this component include a settiing tank, a centrifuge, and a filter.

9. From Bureau of Mines' work ${ }^{22}$ on the equilibrium in a $\mathrm{K}_{2} \mathrm{CO}_{3}-\mathrm{H}_{2} \mathrm{O}-\mathrm{CO}_{2}-$ $\mathrm{KHCO}_{3}$ system, it is calculated that in a batch system, at $100^{\circ} \mathrm{F}$, an equilibrium conversion of about $81 \%$ is possible. Since the carbonator can be a reaction tank containing slurry/solution of $\mathrm{K}_{2} \mathrm{CO}_{3}$ with a continuous sparge of the flue gases containing $\mathrm{CO}_{2}$, it is assumed that about $80 \%$ of the $\mathrm{K}_{2} \mathrm{CO}_{3}$ introduced in the combustor will be converted to $\mathrm{KHCO}_{3}$. 
10. As in the PERC process, a Stretford unit is selected to recover sulfur. In the absence of adequate information, rigorous analysis around the Stretford unit is not possible. Also, the $1 \%$ loss of potassium that was attributed to the seed regeneration scheme (due to conversion efficiency or operating loss, etc.) is assumed to be incurred equally as $\mathrm{K}_{2} \mathrm{SO}_{4}$ and $\mathrm{K}_{2} \mathrm{CO}_{3}$.

Based on these assumptions and the flow sheet shown in Fig. 3, compositions and energy contents of the major components were calculated for the various streams. These results are given in Tables 6 and 7 . 
Table 6. Flow Chart for Scheme Based on Modified Tampella Process

Basis: 1000 wWt plant

Illinols 16 conl feeding rate $=270,000 \mathrm{lb} / \mathrm{hr}$

Seed feed rate to WID plant $=46,800 \mathrm{hb} / \mathrm{hr}\left(85\right.$ wt $\left.\times \mathrm{K}_{2} \mathrm{CO}_{3}\right)$

\begin{tabular}{|c|c|c|c|c|c|c|c|c|c|c|c|c|c|c|c|c|}
\hline \multirow[b]{2}{*}{$\begin{array}{l}\text { Procese } \\
\text { Strente }\end{array}$} & \multicolumn{8}{|c|}{ Stream Componeats, $1 \mathrm{~b} / \mathrm{hr}$} & \multicolumn{6}{|c|}{ Gas Components, $1 \mathrm{~b} \cdot \mathrm{mo} 1 / \mathrm{hr}$} & \multirow[b]{2}{*}{$\underset{\text { Tewp., }}{\text { of }}$} & \multirow[b]{2}{*}{$\begin{array}{r}\text { Enthalpy, } \\
10^{6} \text { Btu/hr } \\
\end{array}$} \\
\hline & $\mathrm{x}_{2} \mathrm{SO}_{4}$ & $\mathrm{~K}_{2} \mathrm{CO}_{3}$ & $\mathbf{k}_{\mathbf{2}} \mathbf{s}$ & $\mathrm{KHCO}_{3}$ & KHS & $\mathrm{Ash}^{\mathrm{b}}$ & $\begin{array}{l}\text { Process } \\
\text { Waterc }\end{array}$ & $\begin{array}{l}\text { KCl, } \\
\text { KOH }\end{array}$ & co & $\mathrm{CO}_{2}$ & $\mathrm{H}_{2}$ & $\mathrm{H}_{2} \mathrm{~S}$ & $\mathrm{O}_{2}$ & $\mathrm{~N}_{2}$ & & \\
\hline$A$ & - & -- & -- & - & -- & - & - & -- & -- & -- & -- & - & 557 & 2,090 & 600 & 11.3 \\
\hline $\mathbf{B}$ & 50,600 & 3,480 & - & - & - & 30 & $6,010(1)$ & - & - & - & -- & - & -- & -- & 120 & 1.5 \\
\hline c & $(27,6002$ & 1b/hr washed & Illinois & (6 coal) & - & - & - & -- & $\cdots$ & -- & -- & - & -- & -- & 60 & 222.0 \\
\hline D & $-\infty$ & - & - & - & -- & - & $12,600(8)$ & - & 82 & 954 & 48 & 4 & - & 2,100 & 1,650 & 81.3 \\
\hline $\mathbf{B}$ & 3,760 & - & 31,400 & - & -- & 2,800 & -- & 47 & $-\infty$ & - & -- & - & -- & - & 1,650 & 12.3 \\
\hline $\mathbf{F}$ & - & -- & -- & -- & - & - & 294,000 (1) & - & -- & -- & -- & - & -- & - & 60 & 8.2 \\
\hline$G$ & 3,760 & - & 31,400 & - & -- & 2,800 & $294,000(1)$ & 47 & -- & -- & -- & - & -- & -- & 100 & 20.5 \\
\hline H & - & - & - & -- & - & 2,800 & $140(1)$ & - & -- & - & -- & - & -- & -- & 100 & - \\
\hline $\mathbf{J}$ & 3,760 & - & 31,400 & -- & - & - & 294,000 (1) & 47 & - & $-m$ & - & - & -- & -- & 100 & 20.5 \\
\hline L, M & - & - & - & - & -- & - & $1,980(8)$ & - & 41 & 477 & 24 & 2 & -- & 1,050 & 100 & 3.1 \\
\hline $\mathbf{N}$ & 3.760 & 19,760 & - & - & 20,560 & - & $292,000 \quad(1)$ & 6 & - & - & -- & - & - & -- & 100 & 20.4 \\
\hline $\mathbf{P}$ & - & - & - & - & - & - & $55,900 \quad(8)$ & - & -- & - & -- & 285 & - & $\rightarrow$ & 195 & 64.4 \\
\hline $\mathbf{Q}$ & - & - & -- & -- & - & - & $55,200(1)$ & - & -- & - & -- & - & - & -- & 110 & 4.3 \\
\hline $\mathbf{R}$ & - & - & - & - & - & - & $725(8)$ & $\sim$ & -- & -- & - & 285 & - & -- & 110 & 1.0 \\
\hline $\mathbf{s}$ & - & - & - & - & - & - & - & -- & -- & $-\infty$ & -- & -- & 143 & 536 & 60 & 0.1 \\
\hline $\mathbf{T}$ & - & $\cdots$ & - & -- & - & - & $917(\mathrm{~g})$ & - & -- & -- & -- & 0.1 & -- & 536 & 110 & 1.3 \\
\hline$v$ & $(9,125 \quad 26$ & $b /$ hr oulfur 1 & In form of & water 81 & (rry) & - & -- & - & - & - & -- & -- & -- & - & 110 & 0.2 \\
\hline$y$ & $(94,000$ & 1b/hr atean a & at $14.7 \mathrm{ps}$ & 1a) & -- & -- & - & - & -- & $m$ & -- & $\cdots$ & -- & - & 212 & 108.0 \\
\hline$w$ & $(80,600$ & 1b/hx atean a & at 25 pela & & - & -- & -- & - & - & - & - & -- & -- & - & 240 & 93.6 \\
\hline$x$ & 3.260 & 64,000 & -- & - & - & - & $241,000(1)$ & 9 & - & - & - & -- & -- & -- & 195 & 41.5 \\
\hline $\mathbf{Y}$ & 5,260 & 64,000 & -- & - & - & - & $7,530(1)$ & 9 & -- & - & - & - & - & -- & 100 & 1.4 \\
\hline 2 & - & 8,730 & - & - & - & - & $7,530(1)$ & -- & -- & - & -- & - & -- & -- & 100 & 0.6 \\
\hline 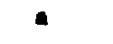 & 1,500 & 15,900 & - & -- & - & - & -- & 3 & -- & -- & -- & -- & - & -- & 100 & 0.2 \\
\hline $\mathbf{b}$ & 1,500 & 4,920 & - & 28,500 & - & - & $5,140(1)$ & 3 & -- & -- & -- & -- & -- & -- & 100 & 0.8 \\
\hline c & 286 & 227 & - & -- & $\cdots$ & - & -- & -- & - & - & -- & - & -- & - & -- & -- \\
\hline d & 3,480 & 719 & -- & - & $-\infty$ & - & - & $-\infty$ & -- & -- & -- & -- & - & - & 60 & - \\
\hline e & 6,950 & 39,900 & $=$ & $=$ & $=$ & $=$ & $=$ & 6 & 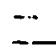 & -- & - & $=$ & -- & - & 60 & $\cdots$ \\
\hline
\end{tabular}

Leter dezigntions refer to calloute in F18 3 ,

bincludes compounds such as $\mathrm{SIO}_{2}, \mathrm{Fe}_{2} \mathrm{O}_{3}, \mathrm{Al}_{2} \mathrm{O}_{3}, \mathrm{CaO}, \mathrm{CaS}, \mathrm{FeO}$, and $\mathrm{K}_{2} \mathrm{SI}_{2} \mathrm{O}_{5}$.

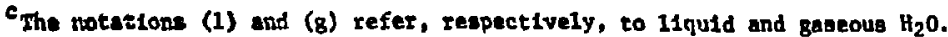


Table 7. Overall Energy Balance for Scheme Based on Modified Tampella Process

Basis: 1000 MNt plant

Illinois \#6 coal feeding rate $=270,000 \mathrm{lbs} / \mathrm{hr}$ Seed feed rate to MHD plant $=46,800 \mathrm{lbs} / \mathrm{hr}\left(85 \mathrm{wt} \% \mathrm{~K}_{2} \mathrm{CO}_{3}\right)$

Energy, $10^{6} \mathrm{Btu} / \mathrm{hr}$

Required

As coal in reduction furnace

To preheat furnace air

In stripper as steam

As steam in evaporator (1st effect)

Subtotal

401

Auxiliary power (10\%)

Available

From quenching of melt $\left(1650^{\circ} \mathrm{F} \rightarrow 100^{\circ} \mathrm{F}\right)$

: From furnace off-gases $\left(1650^{\circ} \mathrm{F} \rightarrow 100^{\circ} \mathrm{F}\right)$

Net Required

$$
\begin{aligned}
\text { Net } & =(\text { total required })-(\text { total available }) \\
& =354 \times 10^{6} \mathrm{Btu} / \mathrm{hr}
\end{aligned}
$$

${ }^{a}$ Low-temperature waste heat available from the precarbonator, evaporator, carbonator, regenerated seed, and gaseous effluent from stripper are not considered here. 
VIII. COMPARISON OF ENERGY REQUIREMENTS FOR PERC AND TAMPELLA PROCESSES

In Table 8, total and net energy requirements for the PERC and Tampe11a processes are compared with similar results avallable from the literature. In Table 9, comparison is made between the calculated energy requirements for the Tampella process, as modified for the potassium system, and the actual energy requirements for the sodium system published by the paper and pulp industry. 5

From Table 8, it is clear that the PERC process has lower energy requirements per pound of potassium than the Tampella process. The higher energy requirements in the latter process can be attributed to higher consumption of coal (for reducfing purposes), and the required evaporation of water.

Table 8 illustrates the variations in calculated energy requirements that are obtained ${ }^{12}$ even for a single process (the PERC process), when different values are assumed for gasifier efficiency and gas utilization.

The comparison made in Table 9 between the calculated energy requirements for the modified Tampella process (for the potassium system) and the energy actually used for the sodium system in industry shows a satisfactory correlation. The difference that is seen can be attributed to (1) differences In the kinetics and thermodynamics of the potassium and sodium systems and (2) the nonoptintized heat-balance computation in the present analysis.

Energy requirements for the Formate and AC processes are also 1isted in Table 8. The Formate process has not yet been ruled out by the MHD community and the AC process (which is described in the AVCO report as the Carbon Reduction process) is very similar to the Tampella process; hence, some consideration of these processes is warranted.

In the Fornate process described in the AVCO report ${ }^{9}$ a seed-recovery step was not employed and the seed-regeneration scheme was considered only up to the production of potassium formate (instead of the more conventional $\mathrm{K}_{2} \mathrm{CO}_{3}$ ). Because of this modification, the AVCO report claims that the scheme will have a low energy requirement. From Table 8 it can be seen that their statement is correct from the standpoint of net energy requirement but not from the total energy requirement. AVCO's ${ }^{9}$ calculations for the Carbon Reduction process (Aqueous Carbonate process) show a lower net energy requirement than the Tampella process constdered here. Thelr lower net energy for the AC process is possible for two major reasons. The first is that AVCo considered about 40 wt \% solution of potsssium salts in the quench tank $v s$. 11 wt \% solution used in this analysis. Because of this, their energy requirement for removal of water has been greatly reduced. (In the paper and pulp industry, for the black liquor recovery process, a 10 wt \% solution is used for the smelt quenching system. ${ }^{9}$ ) The second reason is that AVCO also gave credit for the thermal energy available in the reduction furnace off-gases, which contained some CO. 
Table 8. Comparison of Energy Requirements per Hour for Various Seed-Reprocessing Schemes (for Illinois Coal)

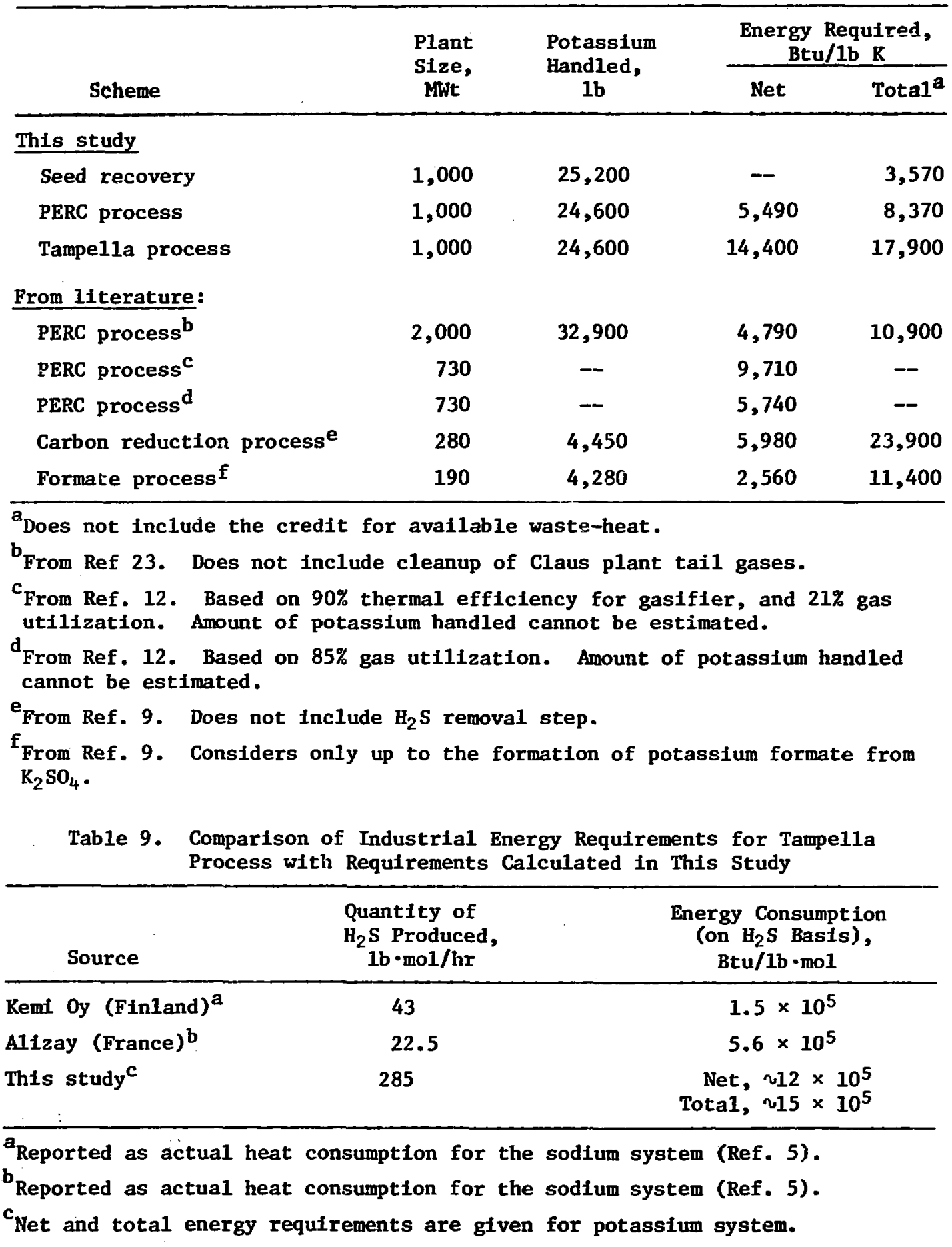




\section{ECONOMIC COMPARISON}

As discussed earlier, an economic analysis was not attempted in this work; however, results of econounic analyses available from the literature are summarized in Table 10.

The reports from Westinghouse ${ }^{12}$ and PERC ${ }^{3,24}$ used different bases to describe their respective plant sizes. For one of the PERC reports, 3 handling capacity in terms of pounds of $i_{2} \mathrm{SO}_{4}$ per hour was estimated from the reported mass balance. Accordingly, as shown in the PERC calculations, \$28.8 allilon was required as a total capital cost $v s$. $\$ 37.3$ million required as a total capital cost by Westinghouse. 12 When the difference in plant size is considered, the agreement in capital cost is considered reasonable. A previous cost estimate of the PERC process, ${ }^{24}$ based on regeneration of seed as $\mathrm{KOH}$, rather than $\mathrm{K}_{2} \mathrm{CO}_{3}$, was $\$ 10.4$ million. The increase to $\$ 28.8$ million ${ }^{23}$ resulted from the additional high-temperature step required for conversion of $\mathrm{K}_{2} \mathrm{~S}$ to $\mathrm{K}_{2} \mathrm{CO}_{3}$.

Also listed in Table 10, are the available cost figures for the Double Alkali process, the Aqueous Carbonate process, and a sulfur throw-away process.

In the Westinghouse analysis, ${ }^{12}$ it is clear that the capital cost for the Double Alkali process is lower than efther the PERC or the AC process. However, the requirement of very dilute solutions to achleve the necessary conversion results in a subsequent, large increase in load in the evaporation step; therefore, the operating cost for the Double Alkall process would be quite high. The operating cost of the potassium throw-away alternative is unacceptably high because of the replenishment cost for the seed (the cost of $\mathrm{K}_{2} \mathrm{CO}_{3}$ is about $\$ 420 /$ ton). The AC process, as revlewed in Ref. 12 had a high capital cost, probably because of its requirement of a two-compartment molten-salt reactor. However, in the revised version ${ }^{15 a}$ of the AC process only a single compartment reactor is used; therefore the capital cost may be somewhat lower. For the PERC process, the reasons for high capital cost were attributed to the requirements of a coal gasifier and a gas-handling section.

The AVCO report ${ }^{9}$ also compares the cost of a seed regeneration process with avallable flue-gas desulfurization (FGD) processes. For a 250-MWt plant fueled with low-sulfur Montana coal, the capital cost for a limestone slurry/flue gas desulfurization system is estimated to be double that of the Formate process. 
Table 10. Economic Comparison of Various Seed-Reprocessing Schemes

\begin{tabular}{|c|c|c|c|c|c|}
\hline \multirow[b]{2}{*}{ Scheme } & \multicolumn{2}{|c|}{ Plant Size } & \multirow[b]{2}{*}{$\begin{array}{c}\text { Estimated } \\
\text { Capital } \\
\text { Cost } \\
10^{6} \$\end{array}$} & \multirow[b]{2}{*}{$\begin{array}{c}\text { Estimated } \\
\text { Annual } \\
\text { Cost, } \\
10^{6} \$^{a}\end{array}$} & \multirow[b]{2}{*}{ Source } \\
\hline & $\begin{array}{l}\text { Power } \\
\text { Rating, } \\
\text { MWt }\end{array}$ & $\begin{array}{c}\mathrm{K}_{2} \mathrm{SO}_{4} \\
\text { Handling } \\
\text { Capacity, } \\
\text { lb/hr }\end{array}$ & & & \\
\hline PERC process & - & 79,200 & 37.3 & 2.95 & \multirow{2}{*}{ Westinghouse, Ref. 12} \\
\hline PERC process & -- & 15,840 & - & 0.84 & \\
\hline PERC process ${ }^{b}$ & 2,000 & 73,400 & 28.8 & - & \multirow[t]{3}{*}{ PERC, ReE. 23} \\
\hline PERC process ${ }^{c}$ & 2,000 & - & 7.56 & 3.69 & \\
\hline Seed recovery $c$ & 2,000 & - & 1.77 & 2.33 & \\
\hline Double Alkali process & - & 79,200 & 7.12 & 2.99 & \multirow{6}{*}{ Westinghouse, Ref. 12} \\
\hline Double Alkall process & - & 15,840 & -- & 0.62 & \\
\hline Aqueous Carbonate process & -- & 79,200 & 44.1 & 2.23 & \\
\hline Aqueous Carbonate process & -- & 15,840 & -- & 0.59 & \\
\hline Throw-Away process & -- & 79,200 & -- & 70.00 & \\
\hline Throw-Away process & -- & 15,840 & -- & 14.00 & \\
\hline
\end{tabular}

ancludes operating and maintenance cost.

${ }^{b}$ Seed recovery and regeneration are included together. Capital cost is given as total capital investment (interest, installation cost, depreciation, etc. are included); $\mathrm{K}_{2} \mathrm{SO}_{4}$ handling capacity is estimated. Regenerated seed is in the form of $\mathrm{K}_{2} \mathrm{CO}_{3}$.

Cotal capital cost is given as $\$ 10,4 \times 10^{6}$; regenerated seed is in the form of $\mathrm{KOH}$. 


\section{$\mathrm{X}$. CONCLUSIONS}

Under the conditions and assumptions of this evaluation study, the PERC process appears to have lower energy requirements per pound of potassium handled than the modifled Tampella process. However, gas uttlization in the PERC process needs to be improved. Although the Tampella process shows higher energy requirements (gross as well as net), it has the distinct advantage that most of its components have been demonstrated successfully, with the sodium system, in the paper and pulp industry. With better furnace design and a different method of quenching the melt, it may be possible to reduce the energy requirements for the Tampella process. Because the Formate process did not meet the requirements imposed as the bases of this evaluation, the Formate process was not analyzed in any detail; however, the work at AVCo $^{9}$ indicates that energy requirements for the Formate procesi are quite moderate. Moreover, the capabilities of the process have been demonstrated in industry.

The capital cost for the PERC process appears to be lower than that for the AC process. The conceptual designs of the Tampella and the AC processes do not differ significantly; thus, it may he assumed that the capital cost for the Tampella process will be somewhat lower than the AC process because the Tampella process does not need a two-compartment molten-salt reactor that appears to have been used in the economic analysis of the AC process. With assumption of a single molten-salt reactor in the Tampella process, the difference in the capital cost between the PERC and Tampella processes should be small. Similarly, it can be concluded that the difference in the annual operating cost between the PERC and Tampella processes will be small. Thus, based on economic considerations, there may not be any significant difference between the PERC and Tampe11a processes.

Another important factor which must not be overlooked is potassium-ash complexing in the AC and Tampella processes. Low-ash petroleum coke could, pertaps, be used in both processes but the operating cost would be higher than with Illinois coal. In this work, it was calculated that, in addition to the $5 \%$ loss that was assumed, a further potassium loss of about $3 \%$ would be incurred in the modified Tampella process. Another potential disadvantage for the AC, Tampe1la and probably PERC processes is the materials problem. The furnace used by Atomics International fo: the AC process has walls constructed of fused alumina; AI claims that this material withstands the attack of molten sodtum salts. However, its resistance to molten potassium salts is uncertain.

\section{RECOMMENDATIONS}

It should be understood that the designs presented herein are preliminary concepts based on theoretical analysis. Application of these concepts directiy to engineering destgn is presented only in a preliminary way. The technical uncertainties inherent in this kind of analysis can be resolved only by additional experimental work either on a bench scale or on a pilot-plant scale. Since none of the processes has a distinct advantage over the others, it is recommended that, if possible, experimental work be carried out for the Modified Tampella as well as the PERC process. More specifically, additional developmental work is recommended $I_{\text {in }}$ the following areas. 
A. Modified Tampella Process

1. The critical component in the modified Tampella process is the reduction furnace. To achieve maximum reduction of $\mathrm{K}_{2} \mathrm{SO}_{4}$ with a minimum amount of coal and a minimum loss of potassium with the ash components, this unit needs the most developmental work. Information such as kinetic rate data, compatibility of construction materials with molten potassium salts, amounts of potassium lost as a function of type of carbon-containing materials, temperature, etc. are also needed to design an efficient furnace.

2. Quenching of the melt is another process step which needs more work. Additional experimental work is needed to determine the conditions and concentrations under which vapor expiosions can be prevented. Atomics International ${ }^{4}$ claims that as an alternative to water-quenching of the melt, the melt can be gas-cooled, solidified, and then broken into chunks for dissolution. Since the solidified melt is quite porous, they think that it will dissolve quickly without any trouble in a lesser amount of water than required for direcî water quenching of the melt.

3. Experimental support is required for the efficient design of the precarbonator, stripper, and carbonator. The information that is available at present is for a fatch system at lower temperatures. Kinetic data for a flowing system for each of these components in the presence of soluble ash compounds and other potassium salts will be quite helpful. Also, the alternative scheme of combining the stripper and carbonator, as in the Aqueous Carbonate process, should be studied in detail to evaluate its impact on $\mathrm{H}_{2} \mathrm{~S}$ concentration, energy consumption, etc.

\section{B. PERC Process}

1. Critical components for the PERC process are the coal gasifier, reducer, and regenerator. A1.1 three need to be developed simultaneously, because the effectiveness of one is reflected in the performance of the others. Kinetic rate data need to be obtained for reducing agents such as mixtures of CO and $\mathrm{H}_{2}$, synthesis gas, producer gas, coal, etc. Fxperiments should be carried out, if possible on a pilot-plant scale, simulating stagewise operation or different reactor geometries with gas recycle to improve gas utilization.

2. In the reduction and carbonation steps, reaction-controlled mechanisms (as yet unidentified) have been suggested as the possible reasons for poor gas utilization in the PERC process, rather than mass transfer or gaseous diffusion-controlled mechanisms. 9 If this is true, then catalytic reaction or reaction under slight gas pressure might prove advantageous. In other words, reduction and regeneration steps of the PERC process should be examined under MHD environments with the aim of understanding the basic reaction mechanisms. In this way, poor gas utilization and low overall reaction rates might be eliminated. Some of the ash compounds are reporied to show catalytic activity, and their use as catalysts may simplify or eliminate the seed-recovery step, which is aimed specifically at separation of potassium from the ash compounds. 


\section{General}

In addition to the specific areas outlined above, other common areas where additioral work is required are as follows:

1. Thermodynamic data on compounds such as $\mathrm{K}_{2} \mathrm{~S}, \mathrm{KHS}, \mathrm{KHCO}_{3}$, etc. are either inadequate or unreliable. 'To carry out effective equilibrium analyses, reliable values for thermodynamic properties are needed.

2. Materials problems resulting from the use of potassium salts, either molten or in aqueous solution under varying temperature conditions, should be given a high priority. Both erosion and corrosion problems need to be addressed. Helpful information may be obtained from the planned 100-MW demonstration plant at the Huntley station in which the AC process (based on a sodium system) will be used. However, a great number of extrapolations will have to be made in going from a sodium system to a potassium system.

3. In the regenerated seed, a significant amount of chloride (which comes from the coal) will be present as KC1 in the Tampella process and to a lesser extent in the PERC process. It is suspected that the chloride ions may have strong adverse effects on the electrodes as well as the refractories. Ways of removing chloride must be studied.

4. The low energy requirement for the Formace process estimated by AVCo 9 and the use of potassium formate as a seed material in the MHD combustor should be verified. If the guidelines for sulfur recovery are changed to allow for throw-away sulfur compounds (such as $\mathrm{CaSO}_{4} \cdot 2 \mathrm{H}_{2} \mathrm{O}$ ), then the Formate process is certainly attractive. Moreover, it has the advantage of being a proven industrial process.

\section{ACKNOWLEDGMENTS}

The authors thank G. M. Kesser for her editorial assistance and helpful suggestions. 


\section{REFERENCES}

1. H. Markant, University of Tennessee Space Institute, private communication (Dec. 8, 1977).

2. J. Lanier, University of Tennessee Space Institute, private communication (Dec. 9, 1977).

3. J. I. Joubert et al, Kinetics of Regeneration of Spent Seed from MHD Power Generation Systems, presented at 15th Symposium on Engineering Aspects of MHD, University of Pennsylvania, May 24-26, 1976.

4. D. C. Gehri and R. D. 01denkamp, Status and Economics of the Atomics International Aqueous Carbonate Flue Gas Desulfurization Process, Proc. Symp. on Flue Gas Desulfurization, Vo1. II, New Orleans, p. 787 (March 1976).

5. T. Tanner and J. L. Clement, MilZ Applications of the Tampella Recovery Process, presented at 1972 International Sulfite Pulping and Recovery Conference sponsored by TAPPI and Technical Section - CPPA, Boston, Mass. (Oct. 30-Nov. 2, 1972).

6. H. P. Markant, Conversion of Potassium Sulphate to Potassium Carbonate, U.S. Patent 3,127,237 (March 1964).

7. William Leavins, System Design Description of Process to Concentrate and Regenerate Potassium Carbonate Seed at Butte, Montana, MHD Test Facility, Resources Conservation Co., Renton, Washington, unpublished work (1976).

8. Kirk-Othmer Encyclopedia of Chemical Technology, 2nd edition, Vo1. 16, p. 387, Interscience Publishers (1968).

9. F. A. Hals, Engineering Test Facility Conceptual Design, Vols. I \& II, AvCO Everett Research Laboratory, Inc., Everett, Mass., FE-2614-2 (1978).

10. A. L. Mond, Process for the Production of Potassium Carbonate, British Patent 386,208 (May 1932).

11. R. T. Shpall, Claus Technical and Economic Study, report for National Air Pollution Control Administration, OAP Contract EHSD-71-45, She11 Development Company, Emeryville, Calif. (April 1972).

11a. A. J. Moyes and S. Vasan, Holmes-Stretford $\mathrm{H}_{2} \mathrm{~S}$ Removal Process Proved in Use, Oil \& Gas Journal 72(35), 56 (Sept. 1974).

11b. R. E. Matty et al., University of Tennessee Space Institute, private communication (1978).

12. F. D. Retallick, MHD-ETF Design Criteria, Vol. I-IV, Westinghouse Electric Corporation, Advanced Energy Systems Division, FE-2363-1 (Dec. 1977).

13. J. W. Mellor, A Comprehensive Treatise on Inorganic and Theoretical Chemistry, Vo1 IV, p. 604, John Wiley \& Sons, Inc., New York (1963). 
14. S. Strohm, University of Tennessee Space Institute, private communication (1978).

15. German Patent, 457,112 .

15a. D. R. Binns and R. G. Aldrich, Deisgn of the $100 \mathrm{~kW}$ Atomics Intermational Aqueous Carbonate Process Regenerative FGD Demonstration Plant, presented at Fourth Symp. on FGD, sponsored by U.S. Environmental Protection Agency, Research Triangle Park, N.C., Nov. 8-11, 1977.

16. W. F. Bischoff, Jr., and P. Steiner, Coal Converts $\mathrm{SO}_{2}$ to $\mathrm{S}$, Chem. Eng. 82,74 (Jan. 6, 1975).

17. S. Gordon et al., Computer Program for Calculation of Complex Chemical Equilibriun Compositions, Rocket Performance, Incident and Reflected Shocks, and Chapman-Jouguet Detonations, N71-37775, NASA-Lewis Research Center (1971).

18. K. C. Mills, Thermodynamic Data for Inorganic Sulphides, Selenides, and Tellurides, Butterworth and Co., Ltd., London (1974).

19. C. C. Hsu et al., Binary Solution Model for Computation of Equilibrium Compositions, Argonne ivational Laboratory report ANL-77-83 (1978).

20. V. J. Goubeau et al., Das System Kaliumsulfat-Kaliumsulfid, Z. Anorg. Allg. Chem. 236, 45 (1938).

21. J. W. Mellor, A Comprehensive Treatise on Inorganic and Theoretical. Chemistry, Vo1. II, Supplement III, The Alkali Metals, Part 2, p. 1898, John Wiley \& Sons, Inc., New York (1963).

22. J. S. Tosh et al., Equilibrium Study of the System Potassium Carbonate, Potassium Bicarbonate, Carbon Dioxide, and Water, U.S. Bureau of Mines Report No. 5484 (1959).

23. P. D. Bergman et aZ., Economic and Energy Considerations in MHD Seed Regeneration, presented at 16th Symp. on Engineering Aspects of MHD, University of Pittsburgh, May 16-18, 1977.

24. D. Bienstock et al., Air Pollution Aspects of MHD Power Generation, presented at 13th Symp. on Engineering Aspects of MHD, Stanford Iniversity, March 26-28, 1973. 
APPENDIX.

Unit Conversion Factors

\begin{tabular}{lll}
\hline To convert from & \multicolumn{1}{c}{ To } & \multicolumn{1}{c}{ Multiply by } \\
\hline $\mathrm{lb} / \mathrm{hr}$ & $\mathrm{kg} / \mathrm{s}$ & $1.26 \times 10^{-4}$ \\
${ }^{\circ} \mathrm{C}$ & $\mathrm{K}$ & $\mathrm{t}_{\mathrm{K}}=\mathrm{t}_{\mathrm{C}}+273.15$ \\
${ }^{\circ} \mathrm{F}$ & $\mathrm{K}$ & $\mathrm{t}_{\mathrm{K}}=\left(\mathrm{t}_{\mathrm{F}}+459 \cdot 67\right) / 1 \cdot 8$ \\
$\mathrm{Btu} / \mathrm{hr}$ & $\mathrm{W}$ & $2.933 \times 10^{-1}$ \\
$\mathrm{Ib} / \mathrm{in} .^{2}$ & $\mathrm{~Pa}$ & $6.895 \times 10^{3}$ \\
$\mathrm{cal}$ & $\mathrm{J}$ & 4.19 \\
$\mathrm{Btu} / \mathrm{lb}$ & $\mathrm{J} / \mathrm{kg}$ & $2.328 \times 10^{3}$ \\
$\mathrm{lb} \cdot \mathrm{mol} / \mathrm{hr}$ & $\mathrm{kg} \cdot \mathrm{mol} / \mathrm{s}$ & $1.26 \times 10^{-4}$ \\
\hline
\end{tabular}


Distribution for ANL/MHD-78-4

Interna1:
P. E. Blackburn
D. H. Bomkamp
T. R. Bump
L. Burris
F. A. Cafasso
L. W. Carlson
L. S. Chow
S. A. Davis
E. D. Doss
T. E. Fornek
J. W. Hafstrom
C. Hsu
K. H. Im

\author{
C. E. Johnson \\ T. R. Johnson (2) \\ A. A. Jonke \\ T. F. Kassner \\ G. M. Kesser \\ D. H. Killpatrick \\ D. D. Kuczen \\ K. Natesan \\ J. S. Patten \\ C. V. Pearson \\ M. Petrick \\ E. G. Pewitt \\ R. B. Poeppe1 \\ W. C. Redman
}

R. R. Rohde
M. H. Shackelford
A. C. Sheth (10)
R. N. Singh
A. J. Sistino
K. E. Tempelmeyer
D. S. Webster
R. W. Weeks
R. S. Zeno
A. B. Krisciunas
ANL Contract File
ANL Libraries (5)
TIS Files (6)

\section{Externa1:}

DOE-TIC, for distribution per UC-90g and UC-93 (330)

Manager, Chicago Operations Office

Chief, Office of Patent Counsel, $\mathrm{CH}$

President, Argonne Universities Association

Chemical Engineering Division Review Committee:

C. B. Alcock, U. Toronto

R. C. Axtmann, Princeton U.

R. E. Balzhiser, Electric Power Research Inst.

J. T. Banchero, U. Notre Dane

T. Cole, Ford Motor Co.

P. W. Gilles, U. Kansas

R. I. Newman, Allied Chemical Corp.

G. M. Rosenblatt, Pennsylvania State U.

C. Kolb, Aerodyne Research, Inc., Bedford, Mass.

G. W. Garrison, Arnold Engineering Development Center, Arnold A.F. Station, Tenn.

R. Detra, Avco Everett Research Lab.

F. Hals, Avco Everett Research Lab.

R. T. Barnes, Avco Everett Research Lab.

J. L. Bates, Battelle Pacific Northwest Labs.

R. A. Kitts, Computer Sciences, Inc., Falls Church, Va.

J. Polutchko, Dynatrend Inc., Burlington, Mass.

D. DeCoursin, Fluidyne Engineering Corp., Minneapolis

R. Rosenberg, General Electric Co., Valley Forge, Pa.

C. H. Marston, General Electric Co., Valley Forge, Pa.

J. Cutting, Gilbert Asisociates, Inc., Reading, Pa.

Kaiser Engineers, Dakland, Calif.

J. F. Louis, Massachusetts Inst. Technology

D. Murphree, Mississippi State U.

J. Orth/V. Griffiths, Montana \& MHD R\&D Inst., Butte

J. D. Meglen, Montana Energy \& MHD R\&D Inst.

$J$. Rasmussen, Montana Energy \& MHD R\&D Inst.

G. Seike1, NASA Lewis Research Center

D. Bienstock, Pittsburgh Energy Technology Center

J. L. Scelso, Polytechnic Inst. of New York 
B. Montgomery, Massachusetts Inst. Technology

R. Gibbons, Ralph M. Parsons Co., Pasadena

R. Y. Pei, Rand Corp., Santa Monica

E. Scanne11, Reynolds Metals Co., Sheffield, Ala.

C. A. Hauenstein, Rockwell International Corp., Canoga Park

F. G. Blottner, Sandia Labs., Albuquerque

K. Touryan, Sandia Labs., Albuquerque

R. H. Eustis, Stanford U.

S. Demetriades, STD Research Corp., Arcadia, Calif.

C. Maxwe11, STD Research Corp., Arcadia Calif.

H. Graham, TRW, Redondo Beach

J. Hardgrove, TRW, Redondo Beach

S. Schneider, National Bu. of Standards, Washington

F. W. Reinhold, U. S. Dept. of State, Washington

J. B. Dicks, U. Tennessee

J. Sadler, Westinghouse Advanced Energy Systems Div., Pittsburgh

F. D. Retallic, Westinghouse Advanced Energy Systems Div., Pittsburgh

J. M. Feret, Westingouse Advanced Energy Systems Div., Piltsburgh 